\title{
Valuation Efficiency of Secondary Markets for Formerly Illiquid Assets: The Case of German KG Ship Funds
}

\author{
André Küster Simic \\ Hamburg School of Business Administration, Germany \\ Philipp Lauenstein* \\ Helmut Schmidt University and \\ Hamburg School of Business Administration, Germany \\ Stefan Prigge \\ Hamburg School of Business Administration, Germany
}

Until the outbreak of the most recent shipping crisis in late 2008, German KG ship funds had been a prominent vehicle for investing in, and financing of, global shipping operations. Given that KG shares are not designed to be traded, investors are expected to require higher returns as compensation for illiquidity. Since the early 2000s, secondary market platforms for trading of shares in ship funds emerged. If investors could sell their shares at prices reflecting the fundamentals of their asset, lower returns would be demand. Making use of a novel methodological approach, 341 transactions of container ship funds executed from 2007 through 2012 are analyzed. The results reveal a surprisingly high fundamental-valuation efficiency: The identified pricing-relevant variables explain about $86 \%$ of the variations in the secondary market valuations of the ship funds. However, it is documented that shares in ship funds trade at discount relative to fundamental asset values. (JEL: D47, G12, G14, G31)

Keywords: ship finance; KG funds; secondary markets; informational efficiency; market microstructure

\footnotetext{
* Corresponding author, Email address: philipp.lauenstein@hsbamail.de. We acknowledge valuable remarks and suggestions by Panayiotis C. Andreou (the editor) as well as two anonymous referees, which led to significant improvements of this paper. Moreover, we would like to thank the Fondsbörse Deutschland for providing the transaction data.
}

(Multinational Finance Journal, 2016, vol. 20, no. 2, pp. 127-179)

(C) Multinational Finance Society, a nonprofit corporation. All rights reserved. DOI: $10.17578 / 20-2-2$ 
Article history: Received: 21 January 2016, Received in final revised form: 26 May 2016, Accepted: 7 July 2016, Available online: 30 August 2016

\section{Introduction}

Sources of financing capital-intensive shipping operations have historically been diverse. Even on a global basis, the German KG (German: Kommanditgesellschaft) model has been a very important vehicle for asset-backed equity financing of, and retail investing in, commercial ships over the past three decades. From 2000 to 2008 alone, approximately $€ 20$ billion of equity investments in commercial ships have been raised in the German KG market (Scope, 2013; Johns and Sturm, 2015). Ever since the post-Lehman economic and financial crisis, however, significant new financing activity in the primary $\mathrm{KG}$ market cannot be observed. Nonetheless, a considerable amount of initial equity investments may still be regarded as outstanding in the form of funds owning actively operating ships. This is because KG ship funds are established for 15 to 20 years before the ship is sold and the fund is liquidated.

Shares in a closed-end KG fund are originally not designed for trade. As a result, investors enter into a comparatively illiquid long-term investment. Economic theory suggests that, all other things being equal, higher returns are expected along with decreasing liquidity of an investment because investors require to be compensated for the higher transaction costs that they bear in less liquid markets (see, among others, Amihud and Mendelson, 1986; Pastor and Stambaugh, 2003; and, for a recent review, Amihud and Mendelson, 2015). It may thus be expected that KG ship funds are subject to considerable illiquidity discounts. If the liquidity of shares in such funds then improves due to the emergence of a secondary market, investors' required returns can be anticipated to decrease.

Since the early 2000s, secondary market trading platforms for shares in $\mathrm{KG}$ ship funds have emerged in Germany. However, the mere existence of a secondary market for an asset is a necessary but not a sufficient condition for positive effects on investors' required returns. First, the secondary market must meet minimum liquidity requirements of investors, i.e. substantial volumes can be traded quickly without adversely affecting prices. Second, valuation efficiency of the secondary markets must be at a satisfactory level. That is, willing buyers and 
sellers can expect realized transaction prices to adequately reflect economic fundamentals of traded equity shares. Intuitively, the positive effects of secondary markets increase with the informational efficiency of transaction prices realized in such markets. Against this background, the aim of this paper is to investigate the valuation efficiency of the secondary market for shares in closed-end ship funds. ${ }^{1}$

Available research on the efficiency of the secondary market for ship funds is scarce. Drobetz, Tegtmeier and Topalov (2008) present a conceptual study with a focus on market microstructure. The only existing empirical work by Küster Simic, Prigge and Thönnessen (2008), who show that an index of valuations in the secondary market correlates with the state of the time-charter market, is limited to time-series analysis techniques. This is also true for much of the empirical work on related real asset markets; for instance, the housing market (e.g. Schindler, 2013). It is contributed to the research on valuation efficiency of secondary markets for real assets by proposing a case-by-case approach to study the efficiency of the market for ship funds based on individual transactions. ${ }^{2}$ The existence of reasonably active global markets for secondhand commercial vessels, combined with the availability of corresponding databases, makes the detailed assessment of the efficiency of secondary markets for ship funds more feasible as compared to other (formerly) illiquid assets, such as real estate or life insurance contracts. In consequence, the secondary market for equity investments in ship funds may be considered as an interesting laboratory for investigating the valuation efficiency of secondary markets for related assets classes. The importance of the findings presented in this paper is therefore not limited to investments in ship funds, but the results may also be relevant for comparable illiquid assets. Apart from that, this paper also contributes to at least two existing research streams:

On the one hand, despite the industry's overall economic importance, research on shipping equities has historically been

1. Following this definition, liquidity is understood to be a multidimensional concept. Although the terminology and systematization of the different dimensions of liquidity vary across the literature (see, for instance, Harris, 1990; Liu, 2006), most conceptualizations cover the speed of trading (often: immediacy), the feasible trade volumes (depth), the cost of trading certain volumes (breadth or tightness) and the ability of markets to quickly absorb temporary imbalances in demand and supply (resiliency).

2. On a related note, Pulvino (1998) studies individual transactions in the market for commercial aircrafts but with a different focus, i.e. the impact of sellers' financial constraints on realized transaction prices and the corresponding existence of fire sales. 
comparatively limited. Only since the beginning of the 2000s, empirical studies focusing on shares in exchange-listed shipping companies have gained importance. Kavussanos and Marcoulis (2005) present a review of empirical advancements in this regard. Recently, for example, risk and return characteristics of shipping stocks have been explored by Syriopoulos and Roumpis (2009), Drobetz, Schilling and Tegtmeier (2010) as well as Grelck et al. (2011). Their results emphasize that investments in listed shipping stocks should be regarded as a separate asset class due to their diversification properties, which Küster Simic and Thönnessen (2008), Drobetz and Tegtmeier (2013) as well as Grelck et al. (2014) indicate to similarly hold for equity investments in closed-end KG ship funds. The growing body of literature on shipping equities is added to by studying the valuation of shares in closed-end funds in the secondary market.

On the other hand, market liquidity and its impact on pricing in a number of maritime financial markets is a recent field of attention in empirical research. Generally, the economic intuition that liquidity is a priced factor is confirmed: For instance, Panayides, Lambertides and Cullinane (2013) provide evidence for higher average stock returns for listed U.S. shipping companies with larger illiquidity measures. Determinants of bond spreads of shipping companies are examined by Kavussanos and Tsouknidis (2014), who document that a bond's liquidity is among the key determining factors. Alizadeh et al. (2015) find evidence for a positive relationship between several illiquidity measures and returns in the freight forward markets, indicating the existence of liquidity risk premia. This research stream is complemented in this paper by studying the valuation efficiency of the thin and presumably illiquid secondary market for shares in KG ship funds. In this context, prevailing research suggests that both trading volumes and liquidity (e.g. Jiang and Kryzanowski, 1997; Johnson, 2008), as well as liquidity and informational efficiency (e.g. Chordia, Roll and Subrahmanyam, 2008) are positively related to each other. Thus, valuation efficiency is understood to be enhanced as more individuals participate in the collection and processing of information on the traded assets. Given that trading activity in the secondary market for ship funds has so far remained moderate at best, expectations towards valuation efficiency of the secondary market may thus be hypothesized to be at low levels.

In addition to the above-mentioned contributions to the scholarly literature, the research question of this paper is relevant for different groups of practitioners: From a funding perspective, for example, the 
impact of efficient secondary markets on investors' required return is expected to have an effect on the cost of capital of closed-end funds. This will influence capital budgeting and funding decision-making of ship owners and financiers (Amihud and Mendelson, 2000; Ortiz-Molina and Phillips, 2014). On the investment side, the ability to exit an investment early by selling it on a functioning secondary market may facilitate investors' fundamental willingness to again invest in the primary market. Conversely, again tapping the retail equity market for KG-based financing of ships may be one route for ship owners to move away from traditional high financial leverage levels (Drobetz et al., 2013). Organizers of secondary market platforms may have an interest in the connection between valuation efficiency and market microstructure.

The remainder of this paper is structured as follows: Section II introduces the German KG scheme in more detail. The third section provides an overview of the secondary market for equity shares in $\mathrm{KG}$ ship funds in Germany and related issues with respect to market microstructure theory are laid out as the theoretical foundation for the analysis. Section IV outlines the empirical methodology. Descriptive statistics and the results of the empirical analysis are presented and discussed in section V and VI, respectively. The last section gives a concluding summary.

\section{The German KG model for investments in ships}

The German KG system was established in the 1970s with the objective of project financing assets - first real estate, later ships and other assets - by private retail investors investing in single purpose closed-end funds. Ship funds in Germany have commonly been structured in the legal form of a $\mathrm{GmbH} \&$ Co. KG (i.e. a limited partnership, herein abbreviated as $\mathrm{KG}){ }^{3}$ Tax advantages facilitate the attractiveness of this legal form as an investment vehicle. Here, the fully liable general partner (German: Komplementär) of the KG is a limited liability company (German: Gesellschaft mit beschränkter Haftung, $\mathrm{GmbH}$ ) and private investors take the position of limited partners. In this legal construct, the private investor participates in the profits and losses of the KG in proportion to his equity stake in the fund, whereas

3. See Johns and Sturm (2015) for an extended textbook discussion of ship financing by means of the KG system. 
the risk is essentially limited to the amount of the individual initial equity investment.

The lifetime of a closed-end ship fund can be described in four phases: (i.) during the conception phase, KG funds are structured by issuing houses. (ii.) During the financing (or placement) phase, equity capital is raised from investors and, typically, additional mortgage-backed debt capital is taken out to finance the project. $^{4}$ Tegtmeier and Topalov (2007) observe the initial debt ratio of ship funds to average around $70 \%$. Once the required capital is available, the fund purchases a ship or orders a new ship at a shipyard and becomes the owner of the ship. Participation for new investors will then no longer be possible, i.e. the fund is closed. (iii.) For the period of the operational phase, the trustee administrates the equity contributions made by the investors. Technical as well as commercial management is provided by third-party ship management companies. The operational lifetime of a commercial vessel may last for at least 20 years, rendering KG ship funds as a long-term investment with limited maturity. (iv.) When the vessel is sold or scrapped, the $\mathrm{KG}$ will be liquidated.

From 2000 to 2008 , approximately $€ 20$ billion of equity investments in German closed-end ship funds have been raised from investors in the "gray" capital market; associated debt capital being estimated to be at least twice as high. ${ }^{5}$ Over that period, the proportion of investments in ship funds' equity out of all closed-end funds' equity in Germany increased from $12 \%$ in 1999 to $30 \%$ in 2008 , documenting the popularity of the shipping markets as compared to other assets. However, primary equity placements in the KG market essentially disappeared along with the outbreak of the global economic and financial crisis in late 2008, which also caused charter markets and asset values in the global shipping markets to plunge. Apart from residual initial placements in 2009 and some activity due to equity capital increases, private investors' interest in equity investment in maritime assets has vanished in view of the ongoing shipping market crisis. At the same time, stricter regulatory framework conditions due to the national implementation of the European Union's Alternative Investment Fund Manager (AIFM) directive in Germany reduced the attractiveness for issuing houses to engage in the set-up of closed-end funds. Nevertheless, the considerable amount of outstanding equity

4. Drobetz and Tegtmeier (2013) present an alternative systematization.

5. Market information on closed-end ship funds is taken from Scope (2013). 
investments in illiquid closed-end $\mathrm{KG}$ ship funds has attracted organizers of secondary market platforms to develop and maintain trading facilities to increase the liquidity of the limited partners' interests held in KG funds. ${ }^{6}$

\section{Secondary markets for KG ship funds and market microstructure}

Once shares in KG ship funds have been issued to investors in the primary market in an initial offering, the securities may subsequently be bought and sold in the secondary market (or aftermarket). In secondary markets with no organized form of trading, which was the case for $\mathrm{KG}$ shares until the emergence of secondary market trading platforms, market participants are confronted with high ex-ante transaction costs. These are caused by, for instance, the need to themselves find a creditworthy counterparty for a transaction, establish the legal framework for the transaction and, finally, negotiate the transaction price. Indirect transaction costs are moreover caused by the latent risk of having to agree on transaction prices that do not represent the economic fundamentals of the traded securities. In order to decrease the cost of transacting in the secondary market, organized exchanges (trading platforms) bring together demand and supply, bundle individual market participants' value-relevant information and facilitate institutionalized trading (e.g. Schmidt, 1977).

Centralized secondary market platforms for ship funds have emerged in the early 2000s. By 2008, a nominal amount of approximately $€ 400$ million was traded on secondary market platforms for ship funds in Germany, equaling 59\% of the combined trading volume of KG funds across asset classes in the formalized secondary market during that period. However, following the post-Lehman economic downturn, nominal volumes of traded shares in ship funds fell to $€ 164.9$ million in 2009 (Feri Rating \& Research AG, 2010). Since then, trading volumes

6. In Germany, the AIFM directive was implemented by the AIFM-Implementation Act (German: AIFM-Umsetzungsgesetz, AIFM-UmsG) that caused the existing Investment Act (German: Investmentgesetz, InvG) to be replaced by the new Capital Investment Code (German: Kapitalanlagegesetzbuch, KAGB). In addition, German national legislation to strengthen the rights of retails investors in the "gray" capital market (German: Kleinanlegerschutzgesetz) was passed in spring 2015. See Markwardt and Schröder (2015) for more details in the context of the KG scheme. 
have remained thin. For example, a nominal amount $€ 4.6$ million was traded on the leading German secondary market platform in July 2015 (Fondsbörse Deutschland, 2015).

Following market microstructure theory, secondary market platforms may be analyzed with respect to their institutional structure and trading mechanisms. The institutional structure is concerned with the arrangement of market access for different types of market participants. Here, Drobetz, Tegtmeier and Topalov (2008) identify three - more or less distinct - categories of platforms for secondary trades of shares in KG ship funds: First, so-called "open market platforms" do not have any restrictions for buyers or sellers to engage in trading of any type of fund. Nevertheless, to establish some degree of control of entrance, users have to be registered at the marketplace. ${ }^{7}$ In Germany, the Fondsbörse Deutschland, which is operated by the stock exchanges in Hamburg, Hannover and Munich, represents this kind of secondary market. This paper is concerned with this form of trading organization. Second, KG issuing houses have been observed to create internal trading platforms where trading is limited to shares in KG funds issued by the respective KG house operating the platform. There are typically no restrictions regarding buyers and sellers. However, the above-mentioned AIFM regulation has caused the majority of this type of secondary market platform to be closed by now. Third, institutional investors set up secondary markets for their own interests. The only buyer in this market is the institutional investor itself and the funds traded need to meet the buyer's investment criteria.

The trading mechanism determines how prices in the secondary market are formed. When prices are determined in order-driven auction processes, batch systems and continuous systems may be differentiated (e.g. Stoll, 1992). If auctions are held continuously (given that bids are available), transactions are executed between only two parties. To form a settlement price, the seller quotes a limited or unlimited order and buyers can bid during the auction. In batch auctions, settlement is performed in discrete, predefined time intervals, at the end of which collective prices holding for all executable orders are set to maximize trading volume. The Fondsbörse Deutschland operates a batch auction system. In addition to auction systems, institutional investors' secondary

7. See Madhavan (2000) for a general treatment and Drobetz, Tegtmeier and Topalov (2008) as well as Küster Simic, Prigge and Thönnessen (2008) for an in-depth discussion of secondary markets for ship funds in this respect. 
market venues are usually organized as market maker systems. In this case, the market maker (i.e. the institutional investor) quotes fixed prices at which he is willing to buy equity shares. If sellers agree, transactions are then executed at these fixed prices.

Market microstructure theory is not only useful to study the structure and trading mechanisms of financial markets but also to analyze the market outcome. In this context, the theory of informationally efficient markets has been systemized by, most prominently, Fama (1970, 1991), who defines three hierarchical degrees of informational efficiency: In weak-form efficient markets, prices are seen to reflect all information available in past prices. The semi-strong form states that prices reflect all pricing-relevant information that is publicly available, whereas strong-form efficient prices also include privately held information. Empirical evidence on markets for corporate stocks largely suggests that these are weak-form efficient; results with respect to semi-strong form efficiency are somewhat mixed (e.g. Brown, 2011). The frequent rejection of the strong-form hypothesis is commonly argued to be in accordance with the Grossman and Stiglitz (1980) paradox on the costliness of collecting information. Furthermore, Fama's $(1970,1991)$ conceptualization covers both the ability of markets to accurately reflect fundamental values in transaction prices and the inability to systemically earn excess profits by trading on an available information set, which Tobin (1984) usefully differentiates as "fundamental -valuation efficiency" and "information-arbitrage efficiency", respectively. Focusing on the former, this study is set to assess the fundamental-valuation efficiency of secondary markets for ship funds in terms of how well prices from individual transactions correctly reflect publicly available information about economic fundamentals. As pointed out above, the liquidity effects of organized secondary markets on investors' expected returns are perceived to increase with the valuation efficiency of the market.

\section{Methodological approach}

This study focuses on special purpose funds owning single container ships. The assessment of the valuation efficiency of the secondary market is based on the comparison of the price of the ship held by the KG fund ("fund ship") with a proxy of the fundamental value of this ship ("benchmark ship"). This novel methodological approach refers to 
the law of one price, which predicts that two homogeneous assets (or securities) with identical expected future cash flows should trade at equal prices (e.g. Roll, Schwartz and Subrahmanyam, 2007).

To start with, the asset value of the fund ship $\left(F S_{i}\right)$, as implied by the price of transaction $i$ in the secondary market, is calculated as:

$$
F S_{i}=\left(E_{i} \cdot p_{i}+D_{i} \pm \lambda_{i}\right) \cdot f x_{i}
$$

where the market value of equity is derived from the product of the nominal book value of equity $\left(E_{i}\right)$ and the transaction price $\left(p_{i}\right.$, quoted as a fraction of $E_{i}$ ). $D_{i}$ is the book value of total debt and provisions. Fund-specific information is extracted from the respective annual reports. By applying the exchange rate valid on the transaction day $\left(f x_{i}\right)$, the market value of the fund ship is converted from Euro to US-Dollar, which is the dominating currency in shipping. As a result, since the sample only consists of funds owning single container ships, these calculations yield a market value of the fund ship reflecting the aggregated opinion of secondary market participants.

Although most aspects of the above method to yield the market asset value of the fund ship are straightforward, additional adjustments to the asset and liability sides of the fund's balance sheet are required. These are summarized in vector $\lambda_{i}$ of equation 1 : First, funds usually hold only minor assets apart from the ship itself (mostly cash and accounts receivable), which are assumed to be sold at book value. Second, following standard procedures in the analysis of financial statements according to German accounting standards, almost half of the special reserve with an equity portion (German: Sonderposten mit Rücklagenanteil) is considered as debt. Third, at the end of each quarter, ship funds make redemption payments on debt outstanding (for more details, see Tegtmeier and Topalov, 2007). In this regard, it has to be adjusted for the fact that most transactions in the secondary markets do not take place on the final day of a quarter. ${ }^{8}$ If a transaction takes place on, say, November 15, 2007, the analysis is based on book values as of December 31, 2007. However, this balance sheet describes the financial situation after redemption payments on December 31, 2007, while the preceding redemption payment was made on September 30. It is

8. The reader is referred to the appendix (table A.1) for an overview of the adjustments of the cash and debt positions to account for the time-lag between the respective dates of the fund's balance sheet and the secondary market transaction. 
assumed that from October 1 until November 15, cash for the redemption payment due on December 31 is collected and the cash position is adjusted upwards accordingly. Moreover, it has to be considered that debt as of December 31 is lower than debt as of November 15. Correspondingly, the debt position is corrected. Matters are slightly different, for a transaction in the first quarter of a year. Here, only an adjustment of the cash position is required but not of the debt position.

The proxy value of the benchmark ship $\left(B S_{i}\right)$ is derived from the market for secondhand ships. Critics of such a mark-to-market valuation based on (averages of) comparable transactions in the secondhand market argue that, in particular at extreme points of shipping's boom-and-bust cycles, observable market prices tend to deviate from intrinsic values. ${ }^{9}$ Nevertheless, the use of a mark-to-market approach is motivated by three key reasons: First, empirical evidence - as reviewed by Pruyn, van de Voorde and Meersman (2011) — does not point towards a systematic rejection of the informational efficiency of the market for secondhand vessels. ${ }^{10}$ Second, Cullinane and Panayides (2000) present survey-based evidence that market-based valuation techniques are most frequently made use of among ship owners. Third, the comparative methodology to test for the fundamental-valuation efficiency allows to partially circumvent the "joint hypothesis problem" inherent in conventional tests for market efficiency (Fama, 1970). This is because the empirical approach of this paper does not depend on the quality of a separate equilibrium asset pricing model to estimate expected returns (or prices), for the reason that benchmark fundamental prices can be readily read from the market for secondhand ships. As an application of the law of one price, this approach relates two observable market prices for (almost) identical assets.

Market data for secondhand container vessels is obtained from

9. This discussion led to the emergence of the discounted cash flow-based Long Term Asset Value (LTAV) method, proposed by the Hamburg Shipbrokers Association (German: Verein Hamburger Schiffsmakler und Schiffsagenten, VHSS), as an alleged attempt to avoid inflationary loan-to-value covenant infringements during the post-Lehman shipping crisis. See Albertijn, Drobetz and Johns (2016) for a recent overview of related discussions on vessel valuations.

10. It should also be noted that averages of multiple transactions in the market for secondhand vessels are used as references prices in the analysis. Potential informational inefficiencies on the level of individual transactions may thus be perceived to average out to some degree. 
Clarkson Research Database. Market prices provided by Clarksons summarize transactions settled in the observation month for standard classes of container ships that are clustered in accordance with age and size, which Ådland and Koekebakker (2007) show to be the dominant drivers of secondhand vessel valuations. To be comparable to the fund ship, the price of the benchmark ship is adjusted with respect to size and age by linear interpolation. This is done assuming that a ship's value develops linearly between boundaries of size and age classes. It is, therefore, abstracted from the well-described economies of scale in container shipping (e.g. Cullinane and Khanna, 2000). However, given that the interpolation is performed between relatively narrow ship size classes, this is perceived to have only a negligible influence on the results, if at all. After this procedure, two asset values for every ship in the data set are yielded. One of which is taken directly from the secondary market transaction and the other one is observed in the secondhand market for vessels. The corresponding hypothesis is:

Hypothesis 1: For a secondary market for shares in KG ship funds to display a good fundamental-valuation efficiency, it is indispensable that the state of the market for secondhand vessels is a major determinant of secondary market transaction prices.

To test this first conjecture, the following cross-sectional Ordinary Least Square (OLS) regression model is formulated:

$$
F S_{i}=\alpha+\beta_{1} B S_{i}+\varepsilon_{i}
$$

However, even after adjusting for size and age to align the characteristics of the fund ship and the benchmark ship, certain differentiating characteristics will remain. The ones discussed below may be valuable for the analysis, as long as they can be controlled for: Time-charter contract: Fund ships being traded in the secondary market regularly carry ongoing time-charter contracts, stipulating that the ship is chartered out for a certain period at a certain charter rate per day. Both the term and the time-charter rate are extracted from the funds' annual reports. In contrast, benchmark secondhand values are reported for charter-free vessels. Therefore, the value of the benchmark ship needs to be adjusted accordingly. For this purpose, it is assumed that the benchmark ship is chartered out at the contemporary time-charter rate for the number of days until the charter contract of the fund ship expires 
$(t=0, \ldots, T)$. Time-charter rates are obtained from the Clarksons and are interpolated with respect to size. However, time-charter rates are not only expected to differ with respect to vessel sizes, but also regarding the duration of the time-charter contract. This term structure of charter rates corresponds to expectations about the development of short-term rates over the respective term of the contract (expectations hypothesis of the term structure) and a time-varying risk premium (e.g. Kavussanos and Alizadeh, 2002; Ådland and Cullinane, 2005; Wright, 2007). To account for the existence of a term structure in container time-charter rates, the charter rate of the benchmark vessel is further adjusted to match the outstanding term of the time-charter contract of the fund ship. This is done by linearly interpolating size-adjusted benchmark charter rates based on short-term ( 6 to 12 months) and longer-term (3 years) time-charter contracts. ${ }^{11}$

The value of the ongoing charter contract is calculated from the time-charterer's perspective, i.e. an existing time-charter rate of the fund ship below (above) the current market rate will lead to a discount (premium) as compared to the benchmark ship. ${ }^{12}$ Differences between the daily charter rate of the fund and benchmark ship are discounted to yield the present value of the time-charter contract:

$$
P V\left(C_{i}\right) \sum_{t=1}^{T} \frac{C R B S_{t, i}^{T}-C R F S_{t, i}^{T}}{(1+r)^{\frac{t}{365}}}
$$

where $P V\left(C_{i}\right)$ is the present value of the time-charter contract of the fund ship, $C R F S_{t, i}^{T}$ is the daily charter rate of the fund ship in US-Dollar, $C R B S_{t, i}^{T}$ is the daily charter rate of the benchmark ship in US-Dollar and $T$ is the number of outstanding days of the time-charter contract of the fund ship at the time of the secondary market transaction.

11. This issue has been pointed out by one of the anonymous referees.

12. This procedure is based on the assumption that the term structure of time-charter rates is linear in shape. Although a non-linear term structure may also be conceivable, the available data on different terms of time-charter contracts limits the empirical ability to estimate the actual exponential shape. Moreover, given that outstanding contract terms of the vast majority of fund ships in the sample are between one and three years, and only very few observations show wide-ranging remaining charter periods, it is perceived that the linearity assumption has limited impact on the empirical results. Time-varying behavior of the shape of the term structure, as noted by Koekebakker and Ådland (2004), complicates matters further. 
The assumed Weighted Average Cost of Capital (WACC; $r$ ) is $7.50 \%$, $5.96 \%, 6.61 \%$ and $5.65 \%$ in the respective subsamples. These discount rates are determined with the standard WACC-formula (see Albertijn, Drobetz and Johns, 2016, for an extended treatment): (i.) The cost of equity is estimated based on the Capital Asset Pricing Model. Since Drobetz, Schilling and Tegtmeier (2010) show that exchange-listed container shipping companies have a market beta of 1.00 , the expected return from equity investments in container shipping can be assumed to equal the return from the broad stock market. ${ }^{13}$ Following the analysis by Dimson, Marsh and Staunton (2011), who calculate the geometric average of global stock market returns between 1900 and 2010, an expected return of $9.40 \%$ is assumed for all subsamples. (ii.) The cost of debt is calculated as the sum of the expected return on a risk-free investment and a credit spread to account for default risk. The risk-free rate is set as the respective 10-year LIBOR swap rate at the end of 2007, 2008, 2010 and 2011 and the credit spread is assumed to be 200 basis points (Stopford, 2009). Considering the profit-independent tonnage tax regime prevailing in Germany, tax shields on interest payments are disregarded. (iii.) The cost of equity and debt are weighted based on a leverage ratio of $70 \%$ (Tegtmeier and Topalov, 2007). ${ }^{14}$

Optional time-charter period: Frequently, time-charter contracts are concluded with embedded optional periods, i.e. the charterer of the fund ship receives a European call option to continue the charter period after the fixed period has expired. The ship fund is the writer of this call. The charterer is expected to exercise the call option when the optional charter rate stipulated in the charter contract (strike price) is below the market charter rate upon maturity, i.e. the call is "in-the-money". Option values are composed of the difference between the current price of the underlying and the strike price (intrinsic value) and a potential premium above the intrinsic value (time value). As calculating intrinsic values is

13. Other empirical studies support the view that the shipping industry has beta factor of about 1.0 (e.g. Kavussanos, Juell-Skielse and Forrest, 2003).

14. See table A.2 (appendix) for details on the input parameter for the WACC calculation. For sake of robustness, the WACC is re-estimated based on a variety of alternative input parameters. It appears that the empirical results are not sensitive to the parameters of the WACC calculation. Furthermore, the discount rates used in this paper match the ones initially proposed by the Hamburg Shipbrokers Association to calculate the LTAV, which range between $6.28 \%$ and $7.91 \%$, depending on the age of the particular container vessel (http://www.long-term-asset-value.de/discountrate.php). 
a straightforward task, and the applicability of standard option pricing models to freight markets is an open research question, estimating intrinsic values is started with. Intrinsic values of existing call option are calculated for optional time-charter periods analogously to the approach to determine the present value of charter contracts:

$$
P V\left(C O_{i}^{\text {Proxy } 1}\right)=\sum_{t=T+1}^{T+Z} \frac{\max \left(O R B S_{t, i}^{Z}-\text { ORFS }_{t, i}^{Z} ; 0\right)}{(1+r)^{\frac{t}{365}}}
$$

with

$$
\operatorname{ORBS}_{t, i}^{Z}=\left(\sum_{t=1}^{T+Z} \frac{C R B S_{t, i}^{T+Z}}{(1+r)^{\frac{t}{365}}}-\sum_{t=1}^{T} \frac{C R B S_{t, i}^{T}}{(1+r)^{\frac{t}{365}}}\right) / \sum_{t=T+1}^{T+Z} \frac{1}{(1+r)^{\frac{t}{365}}}
$$

where $P V\left(C O_{i}^{\text {Proxy } 1}\right)$ is the intrinsic value of the charter call option on the fund ship. Any positive option value results in a premium of the benchmark ship over the fund ship. $T$ is the fixed remaining period of charter contract of the fund ship and $Z$ is the maturity of the embedded charter option. The daily option rate stipulated in the option contract $\left(O R F S_{t, i}^{Z}\right)$ is the exercise price. The expected benchmark charter rate during the optional period $\left(O R B S_{t, i}^{Z}\right)$ is approximated by the implied forward time-charter rate. ${ }^{15}$ As demonstrated by Koekebakker and Ådland (2004) as well as Alizadeh, Ådland and Koekebakker (2007), the expected future charter rate is implied by the term structure of time-charter rates based on the following notional construct: First, a given vessel is chartered today for the period $t=0, \ldots, T+Z$ (i.e. the combined fixed and optional charter period) at $C R B S_{t, i}^{T+Z}$. Simultaneously, the same ship is chartered out both from $t=0, \ldots, T$ at $C R B S_{t, i}^{T}$ and from $t=T+1, \ldots, T+Z$ at the forward time-charter rate $C R B S_{t, i}^{Z}$. Assuming that the non-arbitrage condition holds, this financial arrangement should have a net present value of zero, allowing to derive the implied forward time-charter rate $O R B S_{t, i}^{Z}$ from the two intersecting

15. Rygaard (2009) also proposes to estimate the expected charter rate during the optional time-charter period by means of the implied forward time-charter rate. Alternatively, expected future time-charter rates could be derived from forward spot freight rates (Koekebakker and Ådland, 2004). To the present day, however, the container freight forward market is underdeveloped with very few transactions being executed at all. Thus, this market does not appear to qualify as a suitable candidate to derive implied forward charter rates. Moreover, first trades in the container freight forward market are only observable from 2010 onwards and are hence not available for the entire sample of this study. 
observable time-charter contracts $C R B S_{t, i}^{T}$ and $C R B S_{t, i}^{T+Z}$. Variable $C R B S_{t, i}^{T+Z}$ is constructed in the style of variable $C R B S_{t, i}^{T}$ but is interpolated with respect to the combined fixed and optional period (in addition to the size of the fund ship).

Although $P V\left(C O_{i}^{\text {Proxy } 1}\right)$ provides a variable that reasonably reflects most of the value-relevant characteristics of the optional charter periods, it must be interpreted as the lower boundary of the option value. Including the time value in the analysis allows to empirically capture the heterogeneity of embedded options. For example, an option deep out-of-the-money is expected to carry less time value as compared to options that are close to in-the-money. Therefore, the modified Black (1976)-based time-charter option pricing model proposed by Rygaard (2009) is employed. ${ }^{16}$ Following this approach, the value of a European time-charter call option is calculated as:

$$
P V\left(C O_{i}^{\text {Proxy } 2}\right)=\left(\left(\text { ORBS }_{t, i}^{Z} \cdot N\left(d_{1}\right)-\text { ORFS }_{t, i}^{Z} \cdot N\left(d_{2}\right)\right) \cdot A(T, Z+T)\right)
$$

with

$$
\begin{aligned}
& d_{1}=\frac{\ln \left(\frac{\text { ORBS }_{t, i}^{Z}}{\text { ORFS }_{t, i}^{Z}}\right)+\frac{1}{2} \cdot \sigma^{2} \cdot T}{\sigma \cdot \sqrt{T}}
\end{aligned}
$$

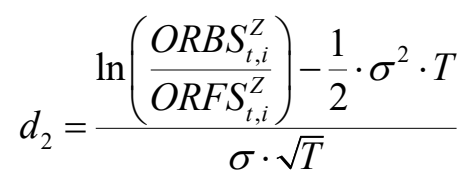

$$
\begin{aligned}
& A(T, Z+T)=\frac{\exp \left(-r_{f} \cdot T\right)-\exp \left(-r_{f} \cdot(Z+T)\right)}{r_{f}}
\end{aligned}
$$

where $N$ is the standard normal distribution function, $\sigma$ is the expected volatility of the respective time-charter rate and $r_{f}$ is the risk-free interest rate. The risk-free rate is the twelve-month LIBOR rate valid by the end of 2007 (4.22\%), 2008 (2.01\%), 2010 (0.78\%) and 2011 $(1.13 \%)$, respectively. It is widely documented in the literature that freight volatility is subject to a volatility term structure (Alizadeh and

16. In addition, the reader is referred to a parallel research stream that is concerned with the pricing of Asian-style options on spot freight rates (see, inter alia, Nomikos et al., 2013). 
Nomikos, 2009; Rygaard, 2009). ${ }^{17}$ Moreover, market risk is shown to differ between ship sizes (Kavussanos, 1996; Glen and Martin, 1998). Therefore, time-charter volatility is adjusted for the term of the optional charter period and ship size to match the individual fund ship. The basis for this procedure is the historical volatility between 2000 and 2012 in different container ship size classes as well as for short-term (6 to 12 months) and longer-term (3 years) time-charter rates. ${ }^{18}$ Historical volatility from the respective size classes and contract terms is then linearly interpolated with respect to the particular fund ship's size and term of the optional period. The mean interpolated volatility in our sample is $28.2 \%$ (annualized). ${ }^{19}$

The above analysis revealed two distinctive characteristics between the fund ship and the benchmark ship that are fundamental with respect to expected future cash flows and can be quantified for the empirical analysis; namely, the value of the charter contract and the value of time-charter option elements. In this case, informational efficiency of the secondary market implies that discrepancies in characteristics between the fund and benchmark ship should be reflected in differences between the fund and benchmark ships' prices. Accordingly, the second hypothesis reads as follows:

Hypothesis 2: For a secondary market for shares in KG ship funds to display a good valuation efficiency, it is indispensable that differences between the fund ship and benchmark ship are reflected in the secondary market transaction prices.

In order to empirically test this second hypothesis, the following refined multivariate OLS regression models are estimated separately, where M2 takes into account existing charter contracts and M3 (a and b) additionally considers possible charter options:

$$
F S_{i}=\alpha+\beta_{1} B S_{i}+\beta_{2} P V\left(C_{i}\right)+\varepsilon_{i}
$$

17. In view of the diminishing sensitivity of time-charter rates to news with increasing contract term, volatility is seen to decrease as time to maturity increases (see Alizadeh and Nomikos, 2009).

18. The results are robust to alternative time frames to estimate historical volatility.

19. As a point of reference, the annualized volatility of the Clarksons Average Containership Earnings Index from 2000 through 2012 was $28.3 \%$. The Clarksons Containership Earnings Index represents the average time-charter earnings across size classes in the container charter market. 


$$
\begin{aligned}
& F S_{i}=\alpha+\beta_{1} B S_{i}+\beta_{2} P V\left(C_{i}\right)+\beta_{3} P V\left(C O_{i}^{\text {Proxy } 1}\right)+\varepsilon_{i} \\
& F S_{i}=\alpha+\beta_{1} B S_{i}+\beta_{2} P V\left(C_{i}\right)+\beta_{3} P V\left(C O_{i}^{\text {Proxy } 2}\right)+\varepsilon_{i}
\end{aligned}
$$

Beyond the factors discussed above, several differences are perceived to exist between the individual fund ships and the generic benchmark ships that are not quantifiable for the purpose of this empirical analysis. These include, but are certainly not limited to, constructional specifications of the fund ship (e.g. technical equipment or the initial constructing shipyard), the creditworthiness of the time-charterer as well as the (cost of) ship management of the fund ship. ${ }^{20}$ However, it appears reasonable to assume that, by accounting for vessel size, a number of constructional attributes of the individual fund ships (e.g. engine speed) are captured as well. This is due to the correlation between ship size and certain technical characteristics (e.g. Cullinane and Khanna, 2000). Furthermore, one may anticipate that the overall technical condition and fuel consumption of a vessel correlate with its age (e.g. Veenstra and van Dalen, 2011), which is controlled for in the empirical analysis.

\section{Data and descriptive analysis}

The sample consists of four separate sample periods that last from 01.10.2007 to 31.03.2008 (subsample 1), from 01.10.2008 to 31.03.2009 (subsample 2), from 01.10.2010 to 31.03.2011 (subsample 3 ) and from 01.10.2011 to 31.03.2012 (subsample 4). Selecting several distinct periods allows to detect potential developments in the valuation efficiency of the secondary market for ship funds over time. These may be induced by, for instance, the fundamental change in the dynamics in the global (container) shipping markets due to the outburst of the severe shipping crisis in the aftermath of the post-Lehmann economic and financial turmoil (e.g. Albertijn, Bessler and Drobetz, 2011).

The sample consists of all transactions in ship funds owning single container ships completed on the secondary market platform of the

20. Critics of the German KG fund model might argue that its hidden costs are so high that it cannot be taken for granted that KG fund management causes a positive net effect for investors. This issue is not raised in this analysis. 
Fondsbörse Deutschland Beteiligungsmakler AG (and its predecessors). This trading platform covers about $90 \%$ of the entire secondary market for trading of closed-end ship funds (Fondsbörse Deutschland, 2015). In addition to the exclusion of funds owning several ships (fleet funds and fund of funds; see Johns and Sturm, 2015), fund ships that, for risk management purposes, share cash flows with other ships in a so-called income pool are excluded. The fact that the reference value of that fund ship is no longer determined only by its specific benchmark ship, but via pooling - by other benchmark ships as well, would introduce unnecessary blur in the analysis, making the results problematic to interpret. The final sample consists of 341 transactions (observations) with an average of 2.14 observations per individual fund, as depicted in table 1 . Here, the number of transactions per fund decreases over time across subsamples. The average ship's age is about 10 years. The severe impact of the economic and financial crisis on container shipping markets is reflected by the observation that market-based estimates of asset values are substantially lower in the later periods (subsamples 2 to 4), while, at the same time, the average fund ship is considerably larger compared to subsample 1 . With respect to indebtedness, the mean market leverage ratio in the sample is $35 \%$. In comparison, Tegtmeier and Topalov (2007) find the average German KG ship fund to debt-finance $70 \%$ of its initial investment. The lower sample value may be attributed to the circumstance that the average vessel in the sample has been operating for approximately 10 years and debt has been paid down accordingly. Correspondingly, Drobetz et al. (2013) show that the average market leverage ratio of listed shipping companies fluctuates around $40 \%$.

The scope of the sample is reflected in the book value of funds as well as in the market values of fund ships and corresponding benchmark ships. Table 2 also reveals the wide range of ship sizes represented in the sample.

The two market values of the fund and benchmark ship stand at the center of the empirical analysis. If the valuation efficiency of the secondary market for ship funds was perfect, and if the fund and benchmark ship were identical, both values should be equal. However, according to table 1 , these values diverge, which seems reasonable given that the two ships are expected to differ with respect to certain characteristics, as discussed above. The values of the fixed time-charter and embedded options should explain a substantial part of this 


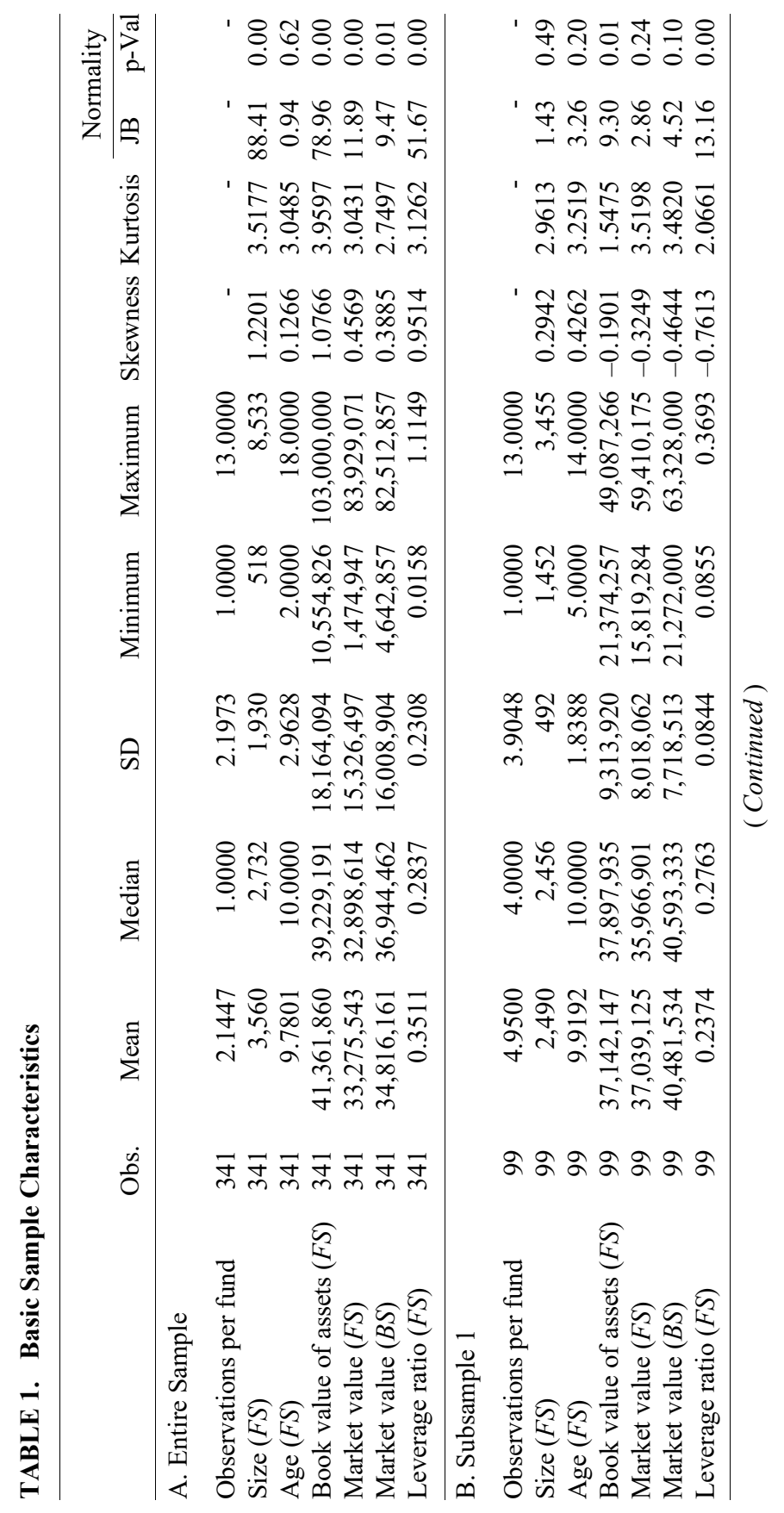




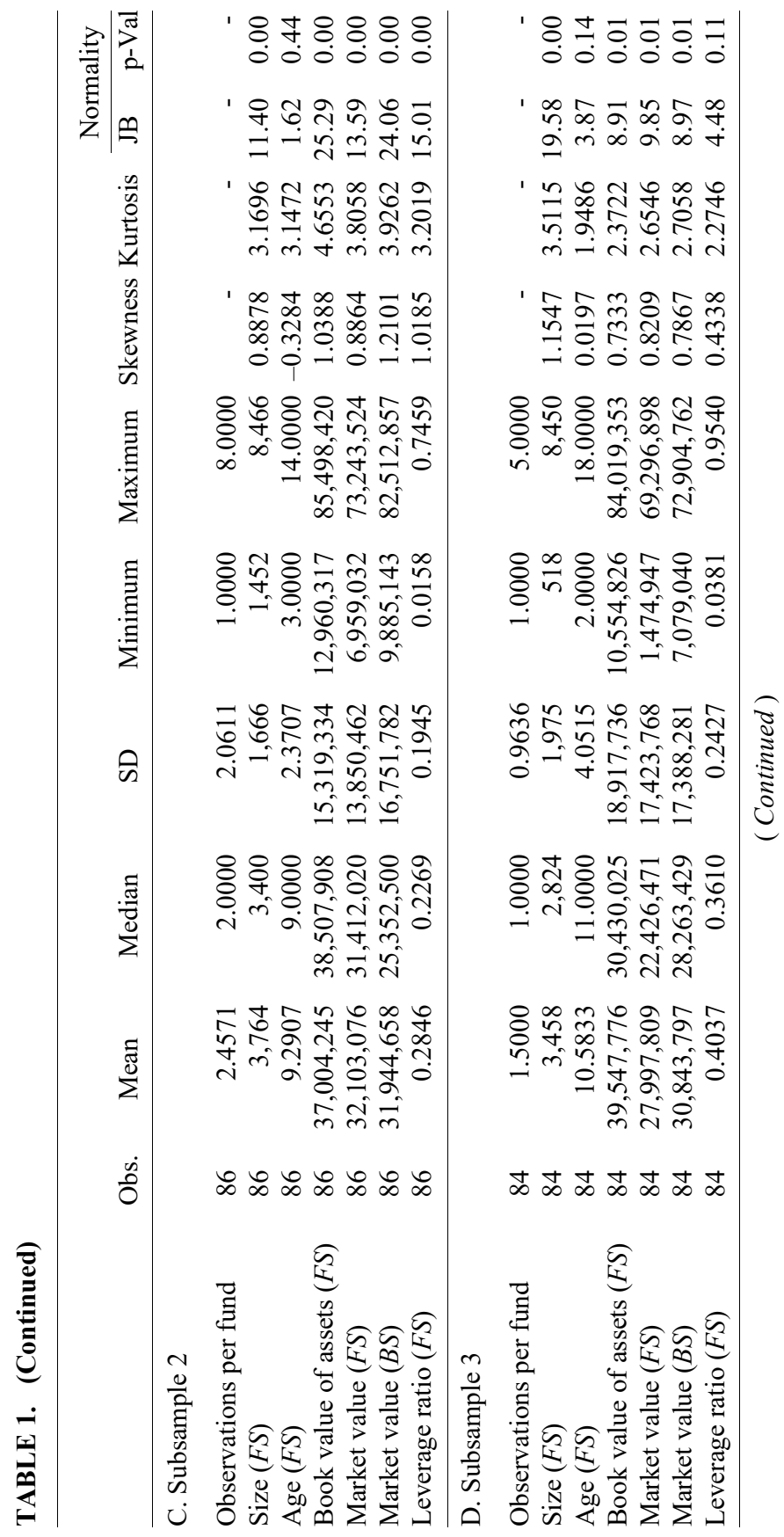




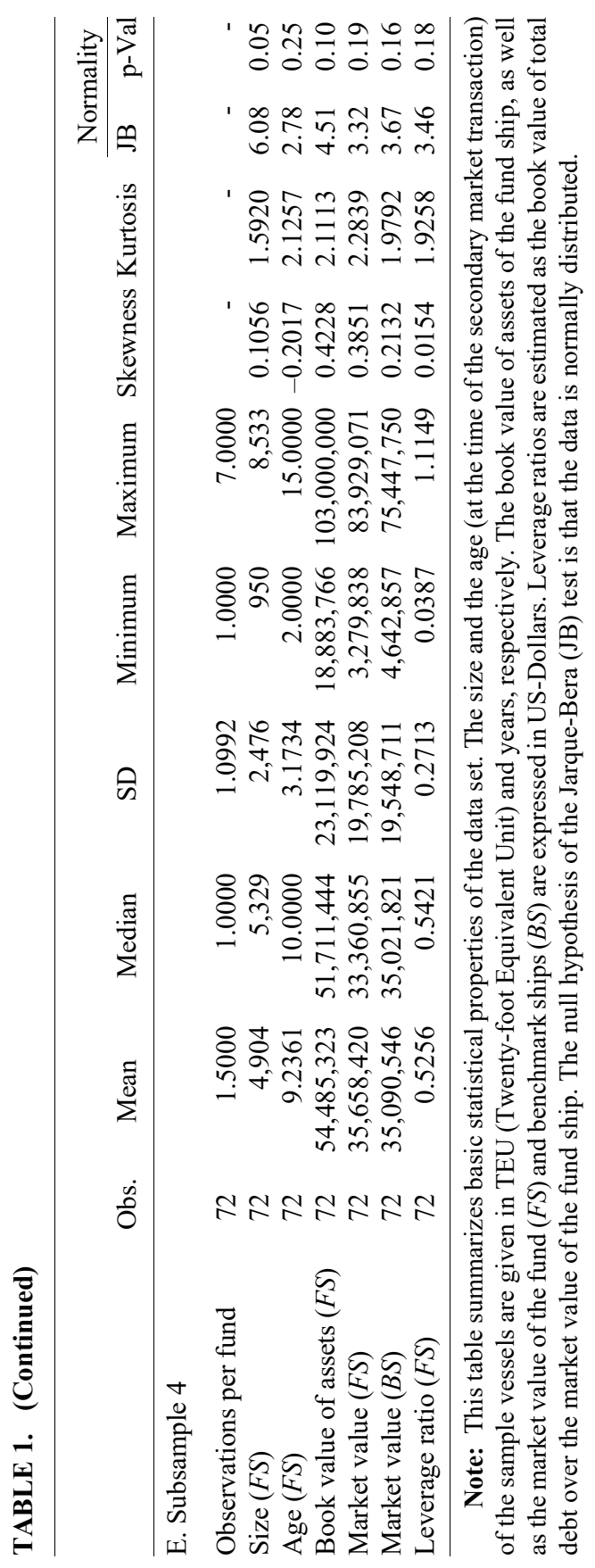




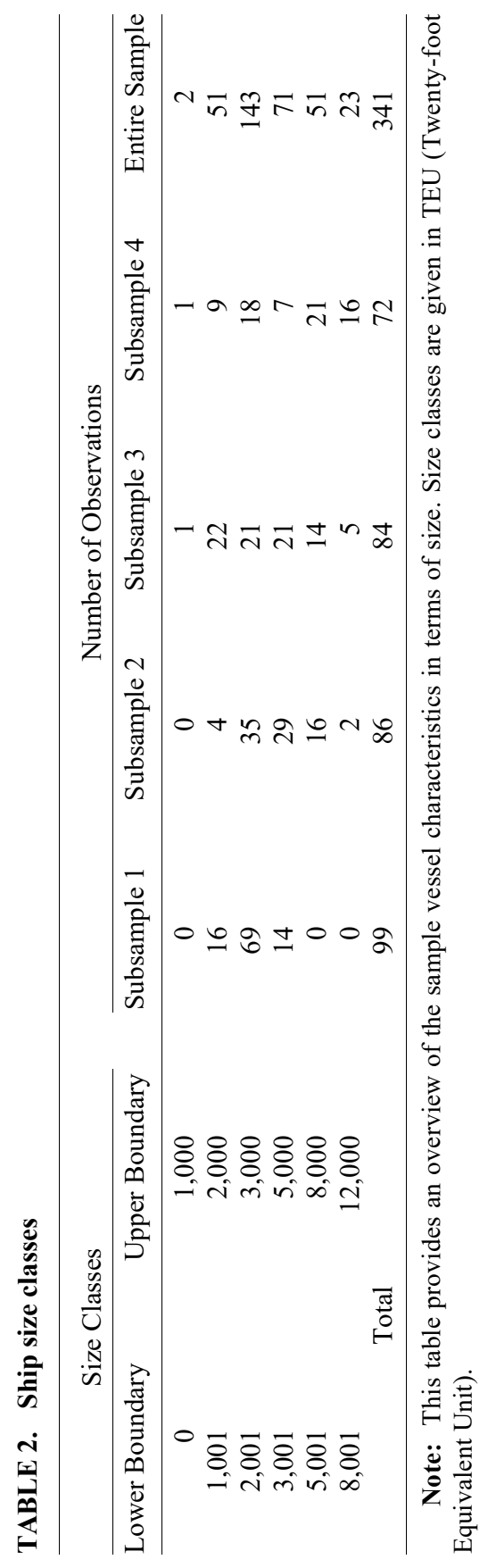




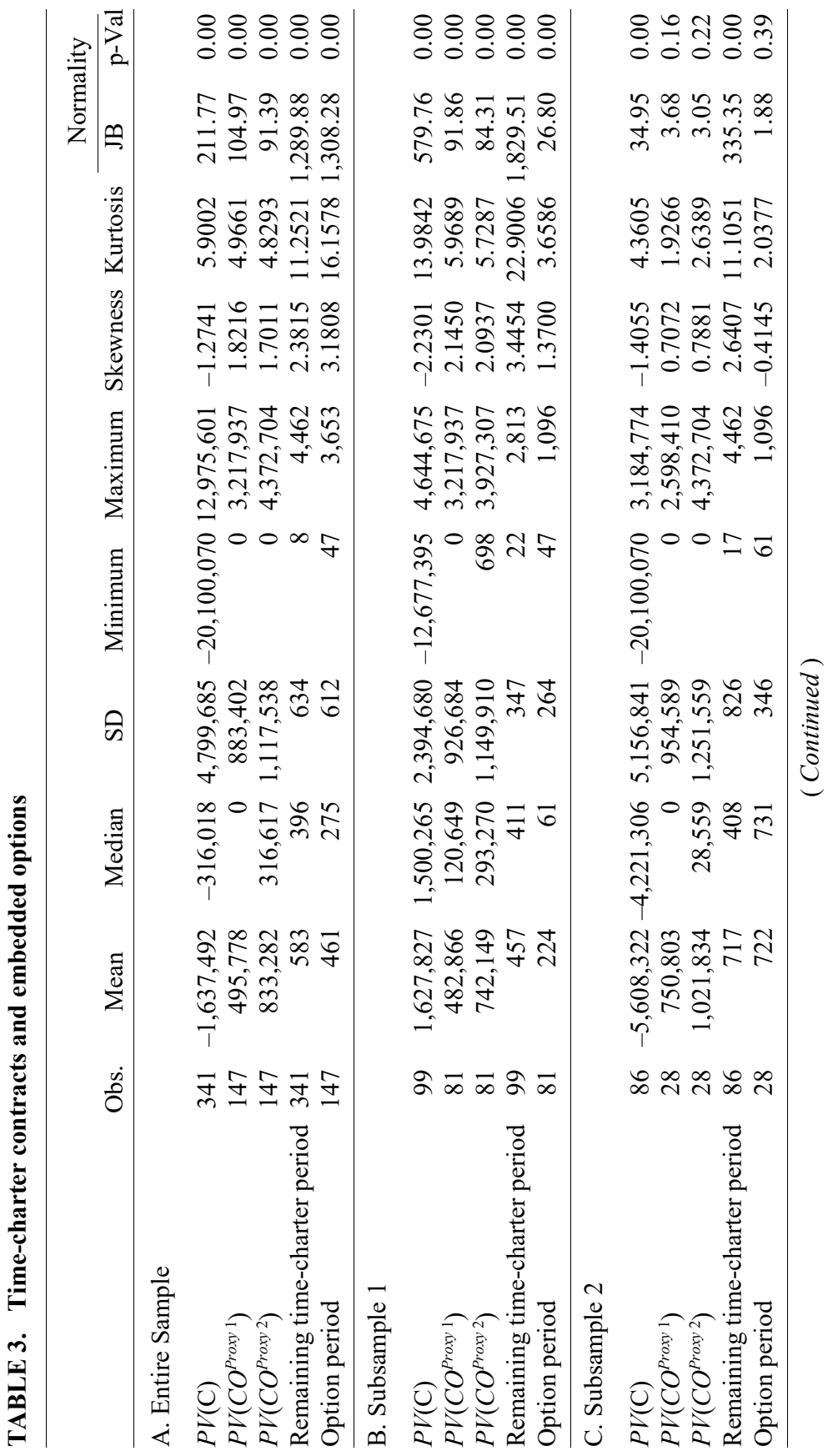




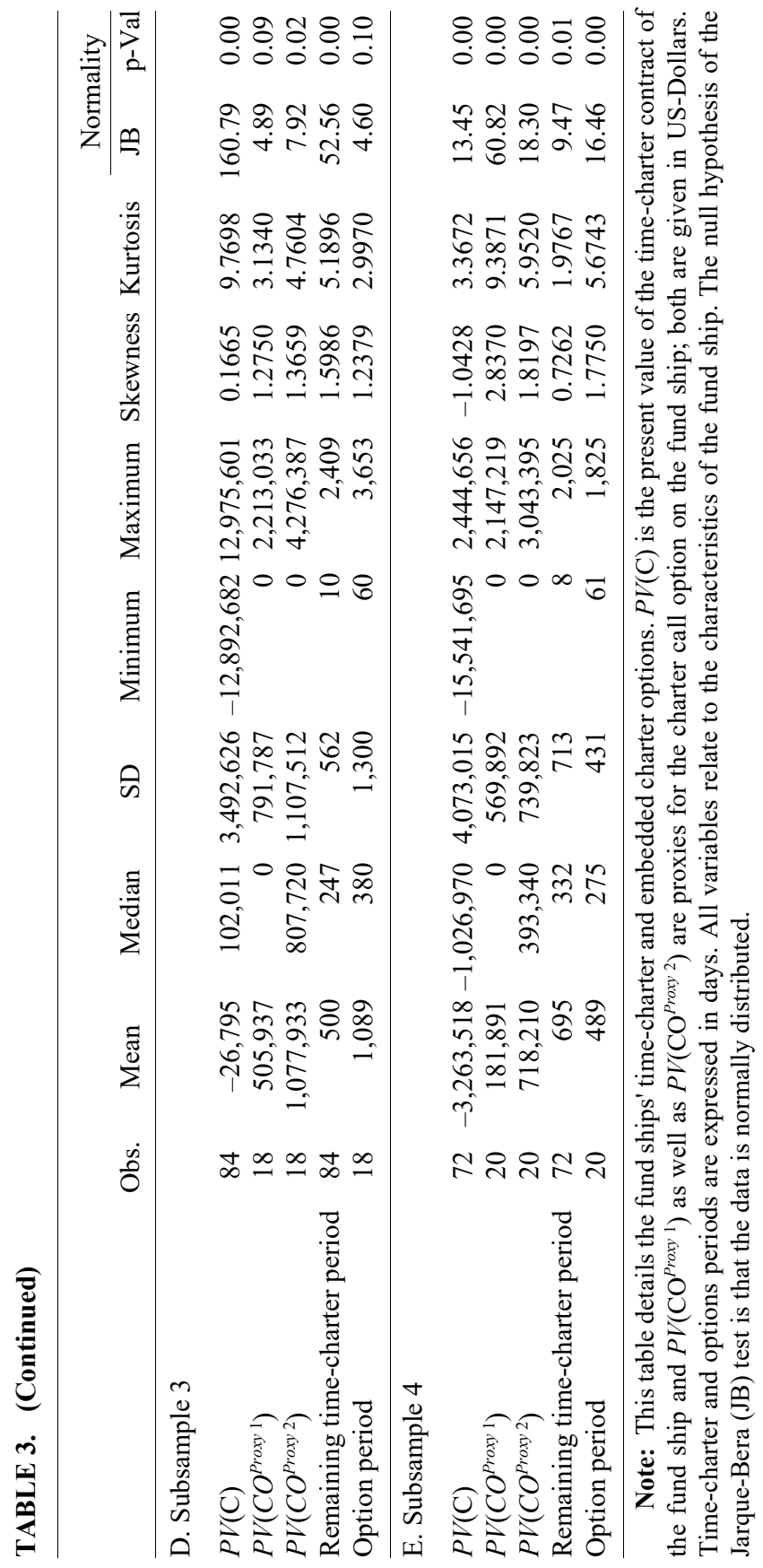


divergence. Here, table 3 summarizes detailed information on these two price determinants. Remaining time-charter periods average between 15 and 23 months in the respective subsamples. The mean option period is about 15 months. High standard deviations point towards significant heterogeneity across the sample, both with respect to fixed and optional charter periods. During the period preceding the outburst of the shipping crisis (subsample 1), the present value of the time-charter contract indicates that, on average, it was unfavorable for the fund ships to be bound by an ongoing time-charter contract because the benchmark charter rate was higher than the contractual charter rate. In contrast, the average fund ship in the sample was able to gain from fixed time-charter rates during subsamples 2 to 4 . Again, the diversity of the sample should be kept in mind when interpreting these preliminary findings.

Further insight into the characteristics of option elements in charter contracts is provided in table 4. Slightly less than half of the observed time-charter contracts contain an embedded option for the charterer to prolong the contract period, $56 \%$ of which are out-of-the-money. That is, the strike option rate is higher than the (implied) forward time-charter rate on the date of the secondary market transaction. Since the charterer is not obliged to exercise the call, the respective options contain no intrinsic value. The remaining $39 \%$ of the options possess a positive parity value and should reduce the fund ship's value relative to benchmark ship's value should, ceteris paribus. The average intrinsic value is US-Dollar 495,778, as represented by the first proxy of the charter option value (see table 3, panel A). Both the intrinsic and the time value of the optional charter period are recognized by the second proxy variable. Therefore, out-of-the-money options are allowed to carry positive values as well, avoiding a potential loss of information. The average of combined intrinsic and time value amounts to almost twice the amount of the first proxy (US-Dollar 833,282). However, it can be read from standard deviations and maximum values that mean charter option values are dominated by few observations with extreme values due to very long option periods (up to ten years). The subsequent empirical analysis will show if, and to what degree, charter option values are recognized in the secondary market for ship funds.

The above preliminary analysis showed that the sample data is characterized by substantial heterogeneity, both within and between subsamples. On the one hand, this heterogeneity makes it problematic to describe the sample features in terms of averages, but, on the other hand, it introduces variance to the sample that may make the empirical analysis more meaningful. 


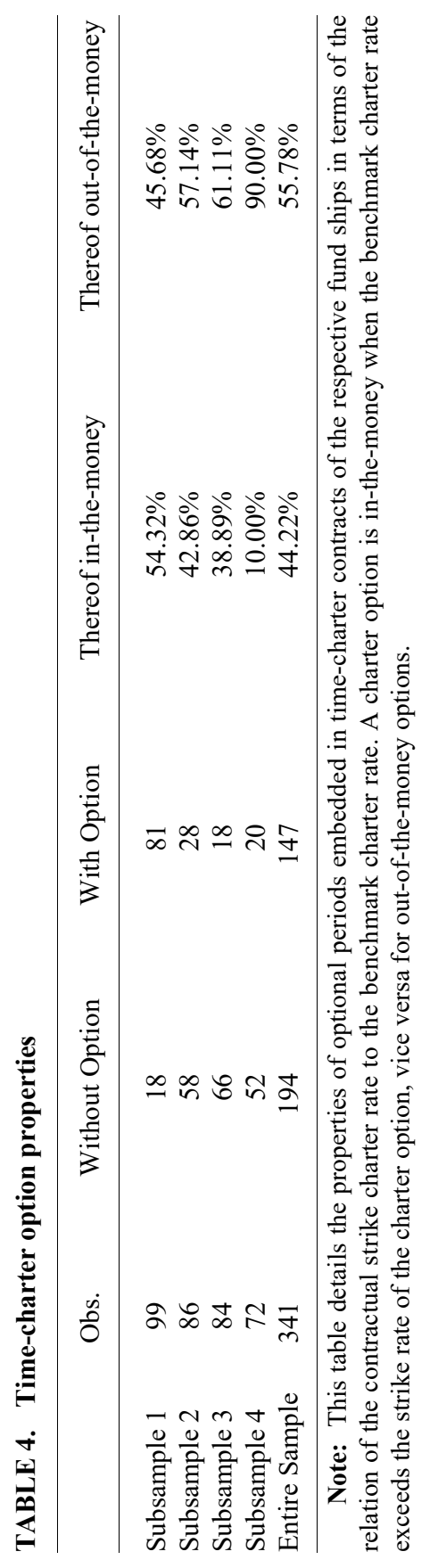




\section{Empirical analysis}

\section{A. Valuation of individual value determinants}

The empirical analysis commences with a visual inspection of the relationship between the value of the fund ship and the corresponding benchmark ship value. Figure 1 points towards a strong linear relation between the two unadjusted measures of vessel values, providing initial support for hypothesis 1 in the sample.

To substantiate this preliminary finding and to incorporate additional presumably value-relevant factors in the analysis, the OLS regression models derived above are estimated. ${ }^{21}$ To improve normality, extreme cases with standardized residual above 2.58 are excluded, corresponding to a $1 \%$ significance level for a two-tailed Z-test. ${ }^{22} \mathrm{After}$ this procedure, the assumption of normally distributed residuals cannot be rejected at the $5 \%$ level of significance or better (see table 5). The assumptions of linearity and homoscedasticity are verified by inspection of scatterplots of standardized residuals (unreported).

Table 5 summarizes the results of the cross-sectional regression analysis. Here, regression 1 confirms the first impression from figure 1 : The fundamental asset value, as proxied by the value of the benchmark vessel, is a major determinant of the valuation of the KG ship fund in the secondary market. This is indicated by the benchmark ship's highly statistically significant coefficient of 0.87 as well as by the observation that $84 \%$ of the variation in the fund ship values are explained by differences in fundamental asset values (see table 5, panel A). It thus appears that the state of the market for secondhand vessels is a major determinant of secondary market transaction prices, pointing towards good fundamental-valuation efficiency (hypothesis 1). Looking at the individual subsamples (depicted in panels $\mathrm{B}$ to $\mathrm{E}$ of table 5), this finding is considerably more pronounced in the latter two periods (subsample 3 and 4).

21. In principle, one would expect the regression line to have a y-intercept of zero. The results are robust to estimating the regression models without a constant term.

22. Although there are only very few cases of exclusions due to this decision rule, all regression models are re-estimated with the full sample (see table A.3, appendix). The results qualitatively match the ones presented in table 5 . 


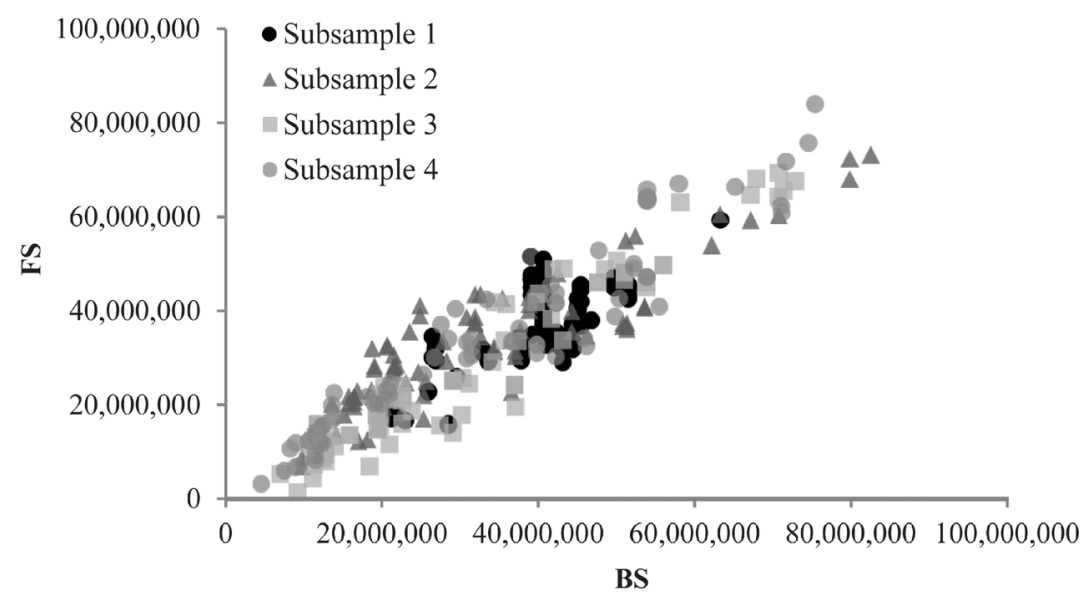

FIGURE 1.- Fund ship values plotted against benchmark ship values

Note: This figure plots the fund ships valuations against the benchmark ship valuations. FS and BS denote the market values of the fund and benchmark ship, respectively; both are given in US-Dollars.

However, both figure 1 and regression 1 in table 5 do not only support hypothesis 1 , they also demonstrate that the relation between the fund and benchmark vessel values is not perfect. Two potential causes for a divergence between both values are quantified within the scope of this paper: The present value of the time-charter contract and the value of a potential option to extend the charter contract. Model 5 and 6 analyze the explanatory power (adjusted R-squared) of both variables for the difference between fund and benchmark ship values. Over the entire sample, the regressors related to the value of the time-charter contract as well as both proxies for complementary charter options are significant. In sum, these two variables explain about $9 \%$ (option proxy 1 , regression 5) and $8 \%$ (option proxy 2 , regression 6) of the variation in the difference in asset values. One conclusion that can be drawn from this result is that including time values of options does not increase the information reflected in the proxy for the option value. Further insight is gained by observing the results from the individual subsamples (regression 5 and 6, panel B to E). Results from subsample 1 show higher power of the entire model in comparison to subsamples 2 to 4 . Thus, the empirical results point towards the non-rejection of hypothesis 2 in the first subsample because value-relevant features of 


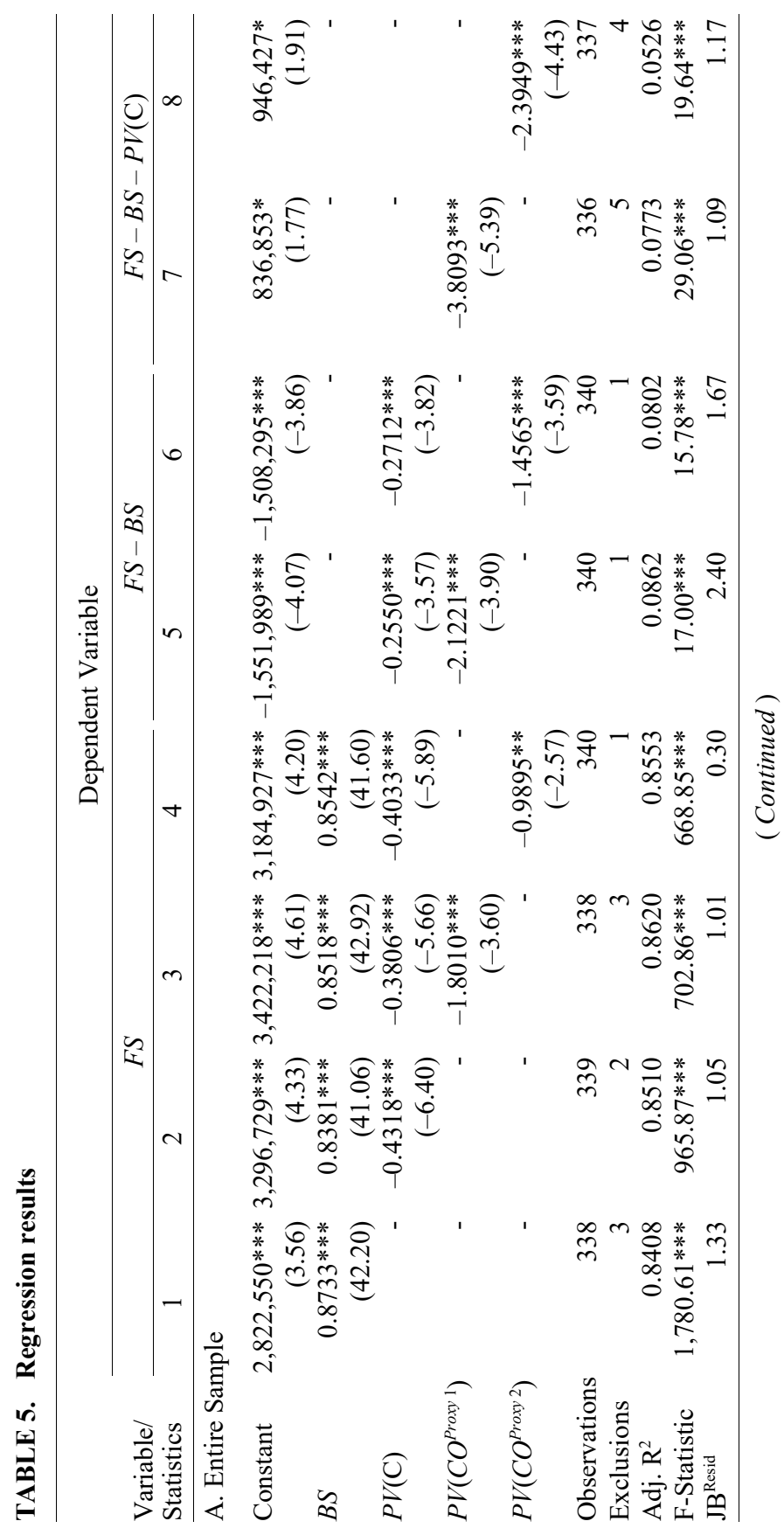




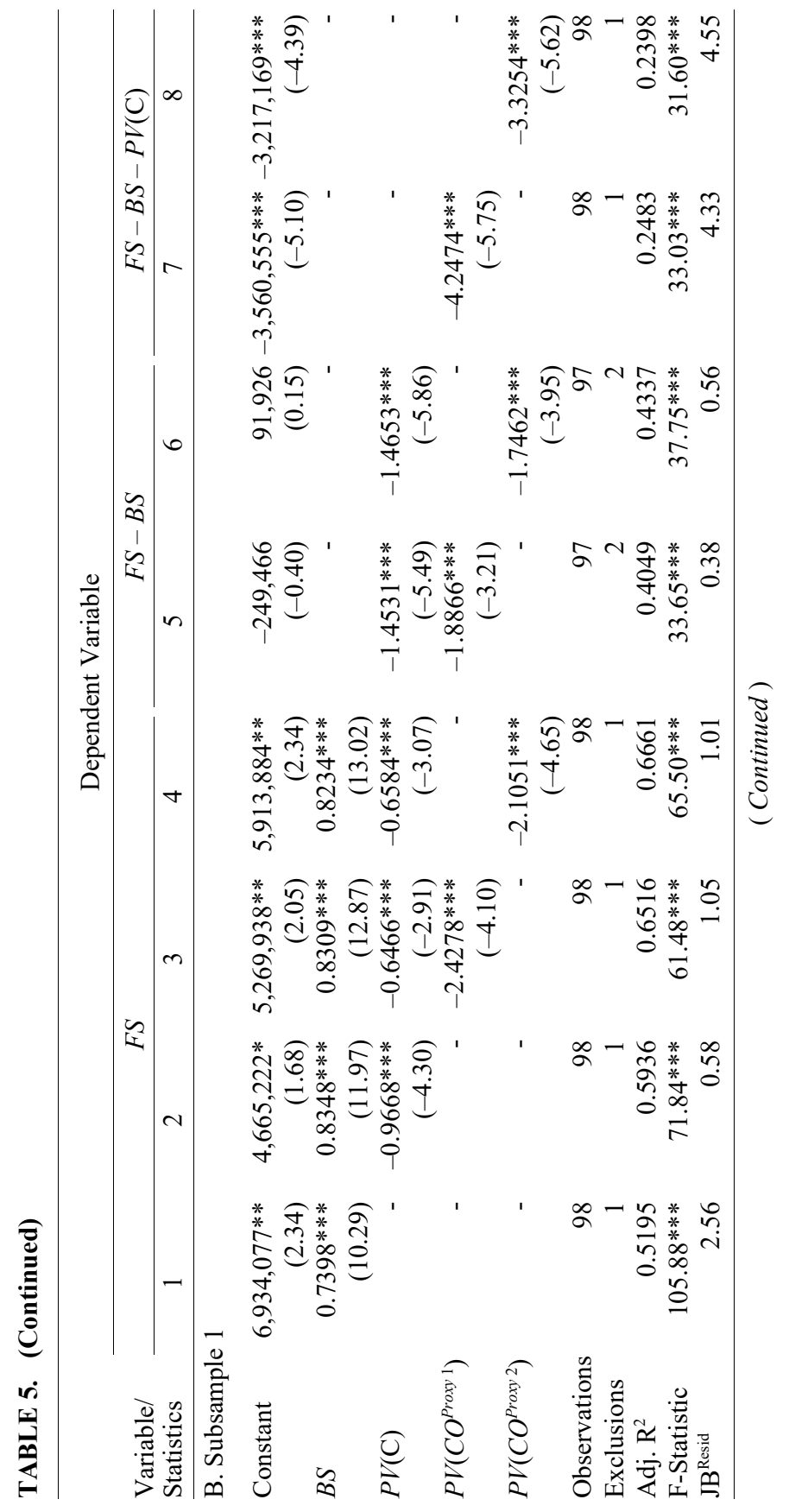




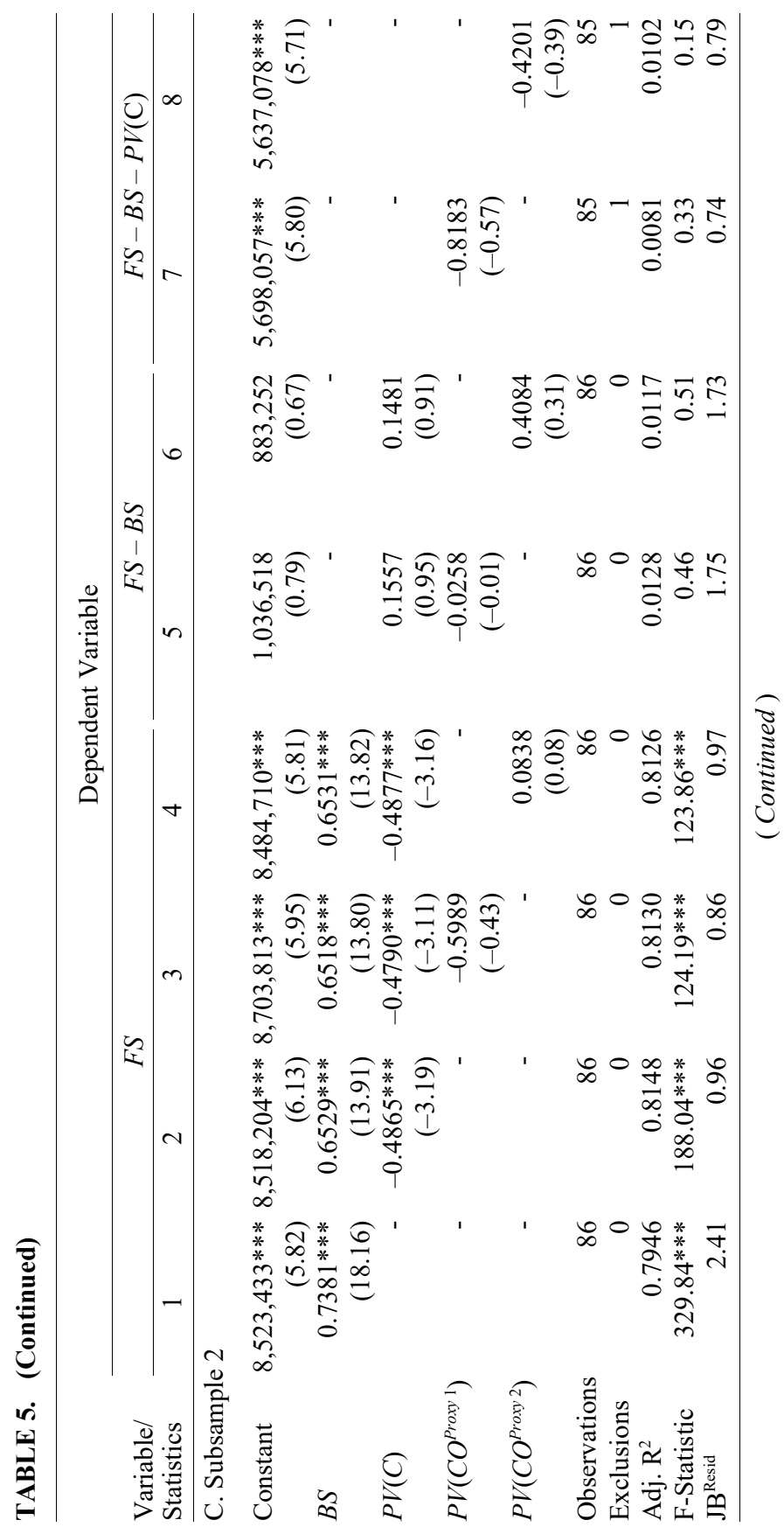




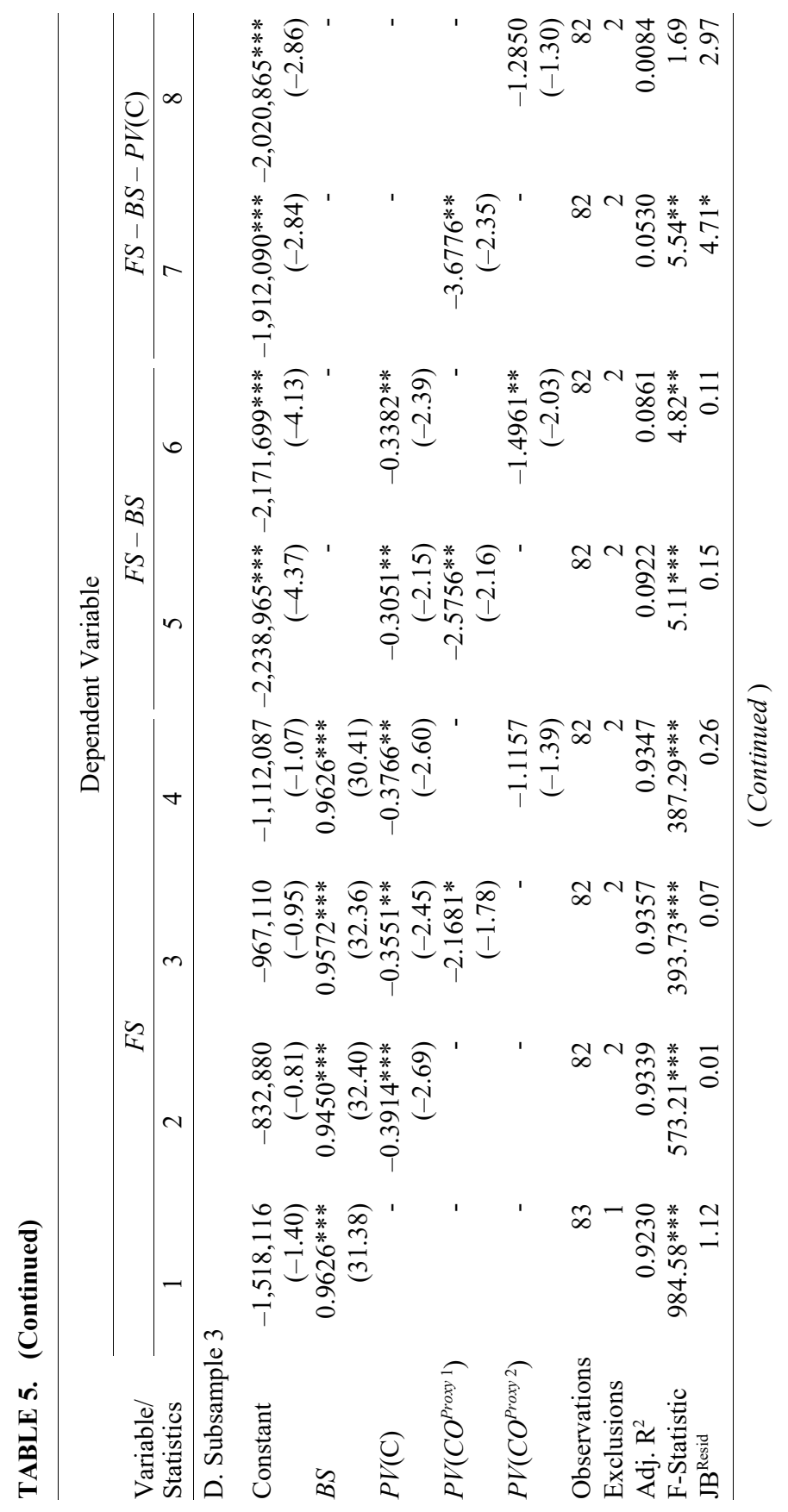




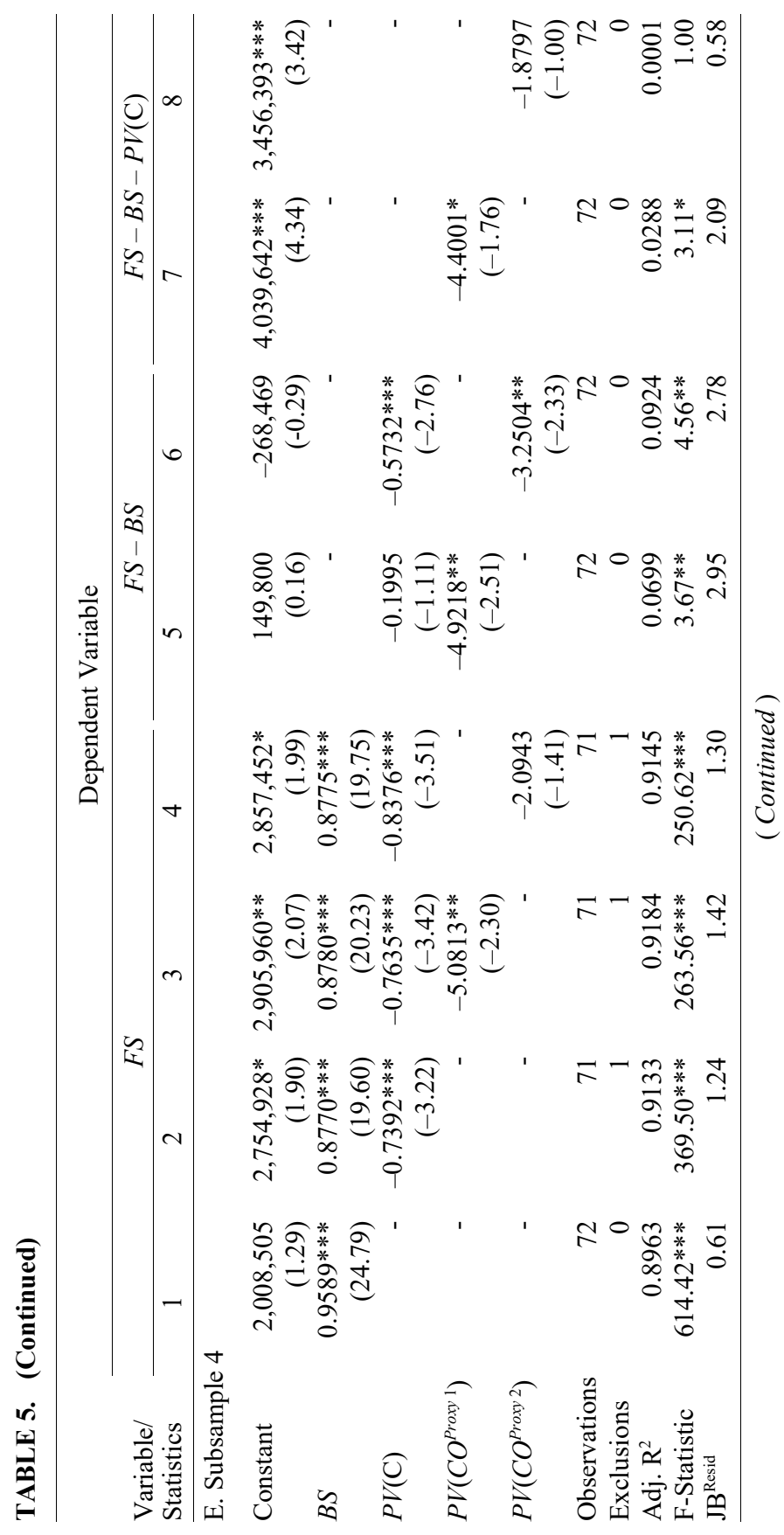




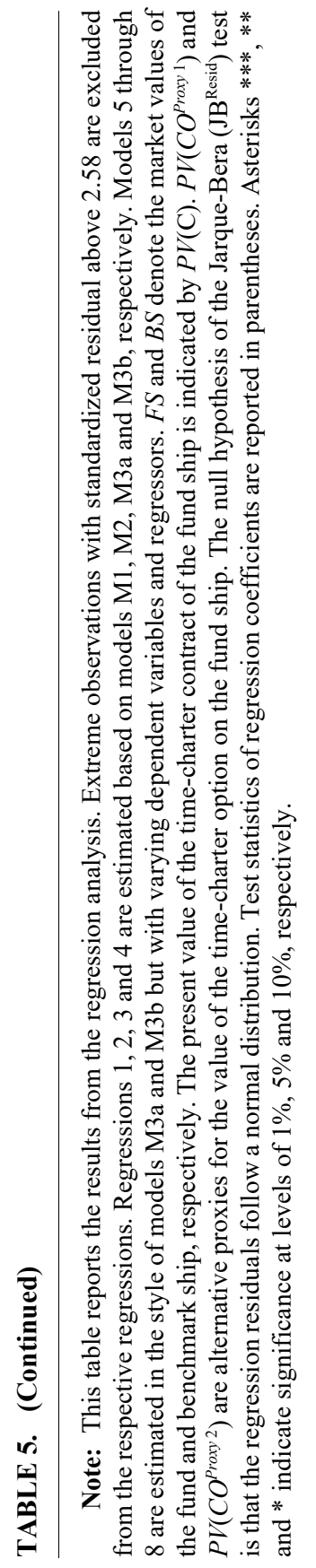


the fund ships' charter contracts are reflected. In contrast, this is not consistently the case in the latter subsamples of the analysis. In particular at the time of emergence of the financial crisis (subsample 2), the secondary market appears to fail to appropriately price time-charter contracts and embedded options. This is mixed evidence with respect to the validity of hypothesis 2 .

To focus entirely on the appraisal of option values, the difference between fund and benchmark ship values, now adjusted for the value of the fixed charter period, is regressed on proxy 1 and 2 for the option value (regressions 7 and 8). Here, the mixed findings on the valuation of charter options in the secondary market are underlined. Moreover, $P V\left(C O_{i}^{\text {Proxy } 1}\right)$ again outperforms $P V\left(C O_{i}^{\text {Proxy } 2}\right)$, casting doubt on the pricing of time values of embedded charter options.

In order to estimate the joint explanatory power of the independent variables for the fund ship value, regression 2 in table 5 regresses the fund ship value on the benchmark ship value and the present value of outstanding time-charter obligations (or benefits) of the ship fund. Taken together, they are able to explain $85 \%$ of the variation in fund ship value over the entire sample. Both regressors are highly significant. The regression coefficient of charter contracts shows the expected negative algebraic sign. Thus, all other things being equal, a positive present value of the charter contract from the charterers' point-of-view significantly reduces the value of the fund ship as compared to its respective benchmark value. To add the value of optional charter periods to the analysis, regressions 3 and 4 are estimated. The regression coefficient of $P V\left(C O_{i}^{\text {Proxy } 1}\right)$ is significantly valued, both in the combined valued sample and in the induvial subsamples (again, except for subsample 2). The combined time and intrinsic option value, indicated by $P V\left(C \mathrm{C}_{i}^{\text {Proxy } 2}\right)$, is only significant in the first subsamples (and the full sample). Overall, the adjusted R-squared of the regressions 1 to 4 is amplified by introducing additional cash flow relevant variables in addition to the value of the benchmark ship.

Taken together, figure 1 and regression 1 (table 5) suggest that asset valuations in the secondary market for ship funds are considerably aligned to benchmark asset values observed in the secondhand market (hypothesis 1). Moreover, in support of hypothesis 2, the results demonstrate that present values of existing time-charter contracts significantly contribute the explanation of the difference between values of the fund and benchmark ship. However, the findings with respect to the valuation of optional charter periods are mixed: While intrinsic 
option values appear to be valued in the secondary market, evidence on the combined intrinsic and time value of charter options is less convincing. Additionally, it appears that the pricing of embedded options has temporarily been distorted at the time of the emergence of the post-Lehman financial crisis (subsample 2).

Since trading volumes in the secondary market for ship funds are low and valuation efficiency in other capital markets has empirically been observed to increase with trade volumes (e.g. Chordia, Roll and Subrahmanyam, 2008; Johnson, 2008), the above analysis shows a remarkably high fundamental-valuation efficiency. With respect to incorporating central value-relevant components, transaction prices seem to reasonably reflect asset values and determinants of expected future cash flows. Nonetheless, the valuation efficiency displayed in the empirical results is not perfect. So far, it would be speculative to ascribe this fact either to valuation failures in the secondary markets or to value-relevant fund ship characteristics not considered in the empirical model of this paper.

\section{B. Level of valuation}

Table 6 displays the previous results in a less abstract manner and moves the focus of the analysis towards the question if $\mathrm{KG}$ funds on the secondary market trade at premium or discount relative to fundamental asset values. On average, fund ship values amount to $98 \%$ of the corresponding benchmark ship values. This discount increases slightly when considering charter contract details (fixed charter period and charter option), which may hint that in particular the value of charter contracts is underestimated. Scaling the individual ratios by the relative asset value of the respective fund ship (Value-Weighted Index of Discounts of Lee, Shleifer and Thaler, 1991) does not affect this result. The finding that closed-end ship funds trade at discount relative to underlying asset values is in line with related empirical evidence which suggests that closed-end funds investing in exchange-listed equities tend to trade at discount compared to the net asset values of funds (see Cherkes, 2012, for a review). It has to be emphasized, however, that this is an examination of average values. Standard deviations are at a substantial level in all subsamples displayed in table 6. Most revealing are minimum and maximum values. To control for the impact of extreme observation, a truncated mean (TMean) is provided in table 6 .

It can be seen from this analysis that secondary market transactions with 


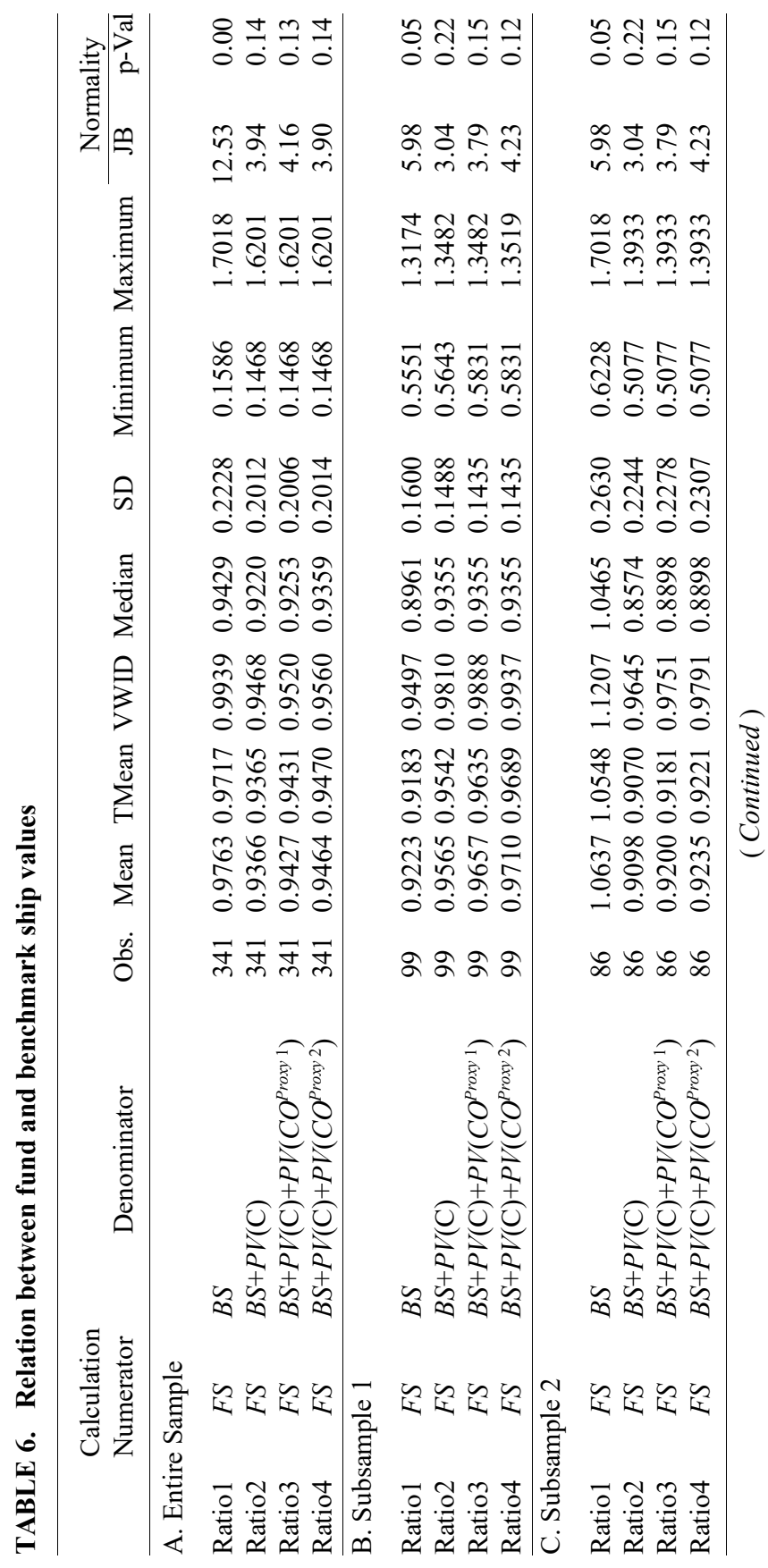




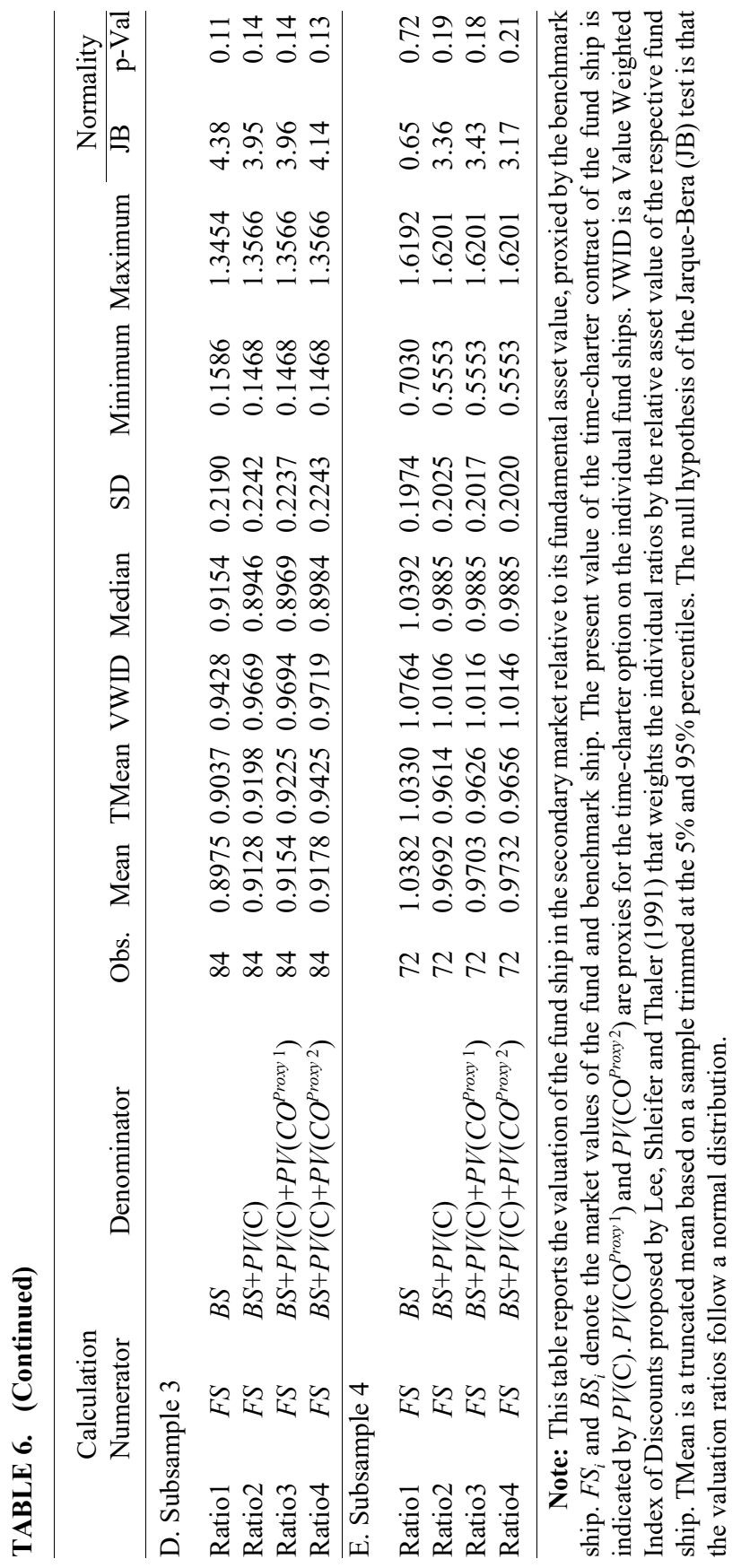


very low/high relative valuations do not appear to distort the above results in terms of averages.

In a sense, there are three competing sources for explanation of the observed average discount of the valuation in the secondary market. The first strand follows traditional rational expectations arguments: First, liquidity requirements of investors may not be fulfilled, causing illiquidity discounts on secondary market prices. In this context, Datar (2001) shows that the discount on U.S. closed-end mutual funds holding stocks increases with the illiquidity of the fund. Second, given that KG ship funds are not exchange-listed and public reporting obligations are comparatively low, fund-specific information beyond general market information may not be available to potential future retail investors, or, at least, costly to acquire (Grossman and Stiglitz, 1980). This applies to, for example, adverse selection risk with respect to the technical condition of the vessel owned by the fund. Third, the management cost structure of KG ship funds may disadvantage the fund ship relative to the benchmark ship, which constitutes an agency theory-based explanation for discounts observed in the secondary market. Behavioral arguments constitute the second school of thought: One of these arguments is based on the assumption that shares in KG funds and the respective benchmark ships are owned by different types of investors that are non-uniformly subject to sentiment. While ship funds are typically held by retail investors (Drobetz and Tegtmeier, 2013), the average benchmark ship is more likely to be owned by professional investors with in-depth market insight. In consequence, the discount on the average $\mathrm{KG}$ fund ship in the sample may be due to the notion that retail investors are more likely to be subject to investor sentiment (e.g. Lee, Shleifer and Thaler, 1991; Baker and Wurgler, 2007, and references therein). Finally, the discount observed in the secondary market may be a result of methodological issues, i.e. the empirical model does not reflect all value-relevant characteristics of the fund ship.

\section{Conclusion}

Until the outbreak of the most recent shipping crisis in late 2008, German KG ship funds had been a central vehicle for equity investing in, and financing of, global shipping operations. It is well known from existing research that investors require lower returns when secondary markets are available where assets can be sold within a reasonable time. 
From the funding perspective, the existence of such a secondary market lowers the cost of capital. However, to cause this effect, a secondary market has to show a high valuation efficiency in terms of prices reflecting economic fundamentals.

To the best of the authors' knowledge, this is the first in-depth empirical effort to analyze the valuation efficiency of secondary markets for equity shares in KG ship funds in Germany. For this purpose, a novel methodological approach is proposed to study 341 transactions of container ship funds in a case-by-case analysis. In sum, the three pricing-relevant components considered in the analysis - i.e. the state of the secondhand asset market, the value of time-charter contract and the value of the call option to continue the charter period - explain about $86 \%$ of the variations in the secondary market valuations of the fund ship. In light of the fact that valuation efficiency is commonly understood to improve with increasing trading volumes, the empirical analysis reveals a surprisingly high fundamental-valuation efficiency. Moreover, it is shown that, on average, shares in KG fund ships trade at discount relative to fundamental asset values. Several potential explanations for this phenomenon are proposed.

It is, however, important to note that the foundation of the results in terms of sample size is limited, in particular, compared to the standards of studies on exchange-listed corporate equities. Nevertheless, the approach reveals promising results and may be a stimulating starting point for future research. An obvious task for future investigations is to enlarge the sample; for instance, by including other market segments such as tanker or dry bulk shipping or other assets like real estate funds. A second strand of future research refers to the number of price determinants considered in the analysis. Additional determinants could include the financial soundness of the charterer, the management cost structure of KG funds or further technical specifications of the fund ship such as engine speed and fuel consumption. 


\section{Appendix}

TABLE A.1. Balance sheet adjustments

\begin{tabular}{|c|c|c|}
\hline & $\begin{array}{l}\text { Transaction on or } \\
\text { before December } 31\end{array}$ & $\begin{array}{l}\text { Transaction after } \\
\text { December } 31\end{array}$ \\
\hline $\begin{array}{l}\text { Adjustment } \\
\text { of Cash } \\
\text { Position }\end{array}$ & $\Delta_{\text {Cash }}=\frac{\text { Date }_{\text {Transaction }}-\text { Date }_{\text {Quarter }}}{90} \cdot R D$ & $\Delta_{\text {Cash }}=\frac{\text { Date }_{\text {Transaction }}-\text { Date }_{\text {BalanceSheet }}}{90} \cdot R D$ \\
\hline $\begin{array}{l}\text { Adjustment o } \\
\text { Debt Position }\end{array}$ & $\Delta_{D e b t}=R D$ & $\Delta_{D e b t}=0$ \\
\hline
\end{tabular}

Note: This table presents an overview of the adjustments of the cash and debt positions to account for the time-lag between the respective dates of the fund's balance sheet $\left(\right.$ Date $\left._{\text {BalanceSheet }}\right)$ and the secondary market transaction $\left(\right.$ Date $\left._{\text {Transaction }}\right)$. Date ${ }_{\text {Quarter }}$ is the first day of the last quarter of a year (October 1 ) and $R D$ is the value of the fund's quarterly redemption payment. 


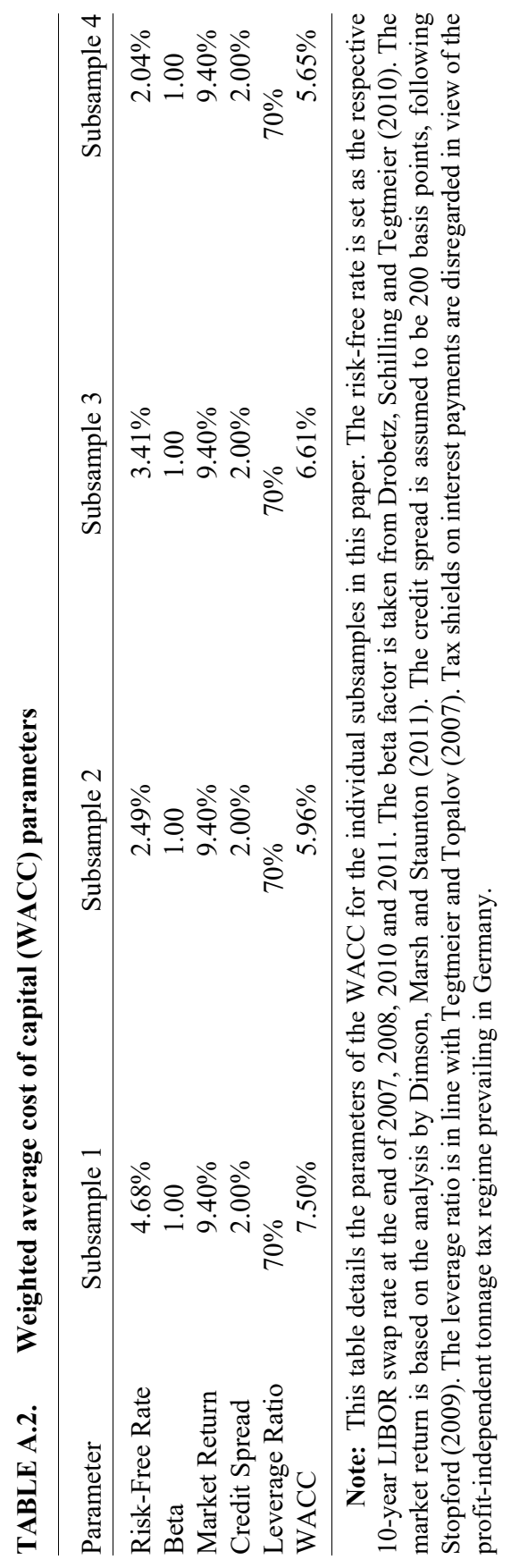




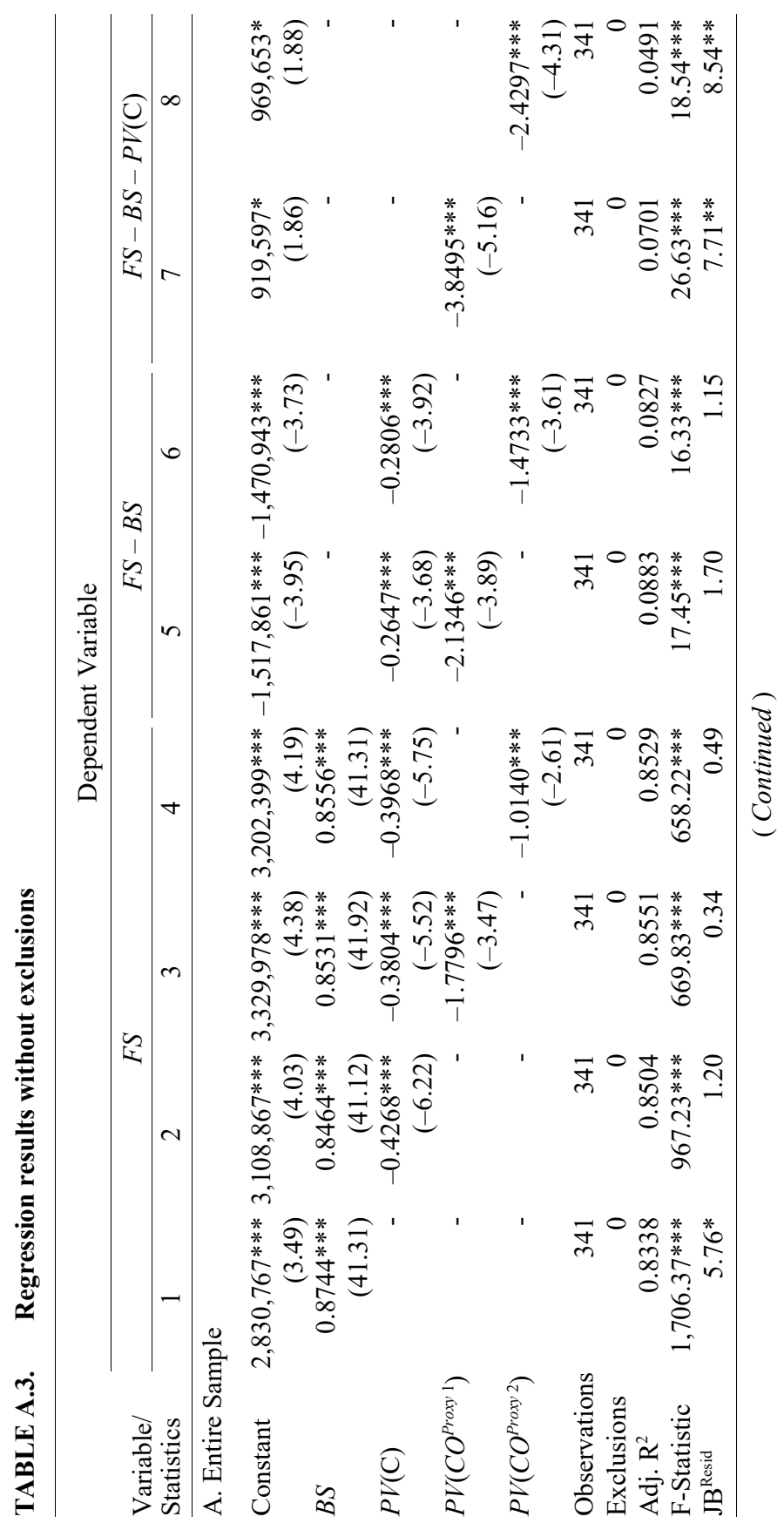




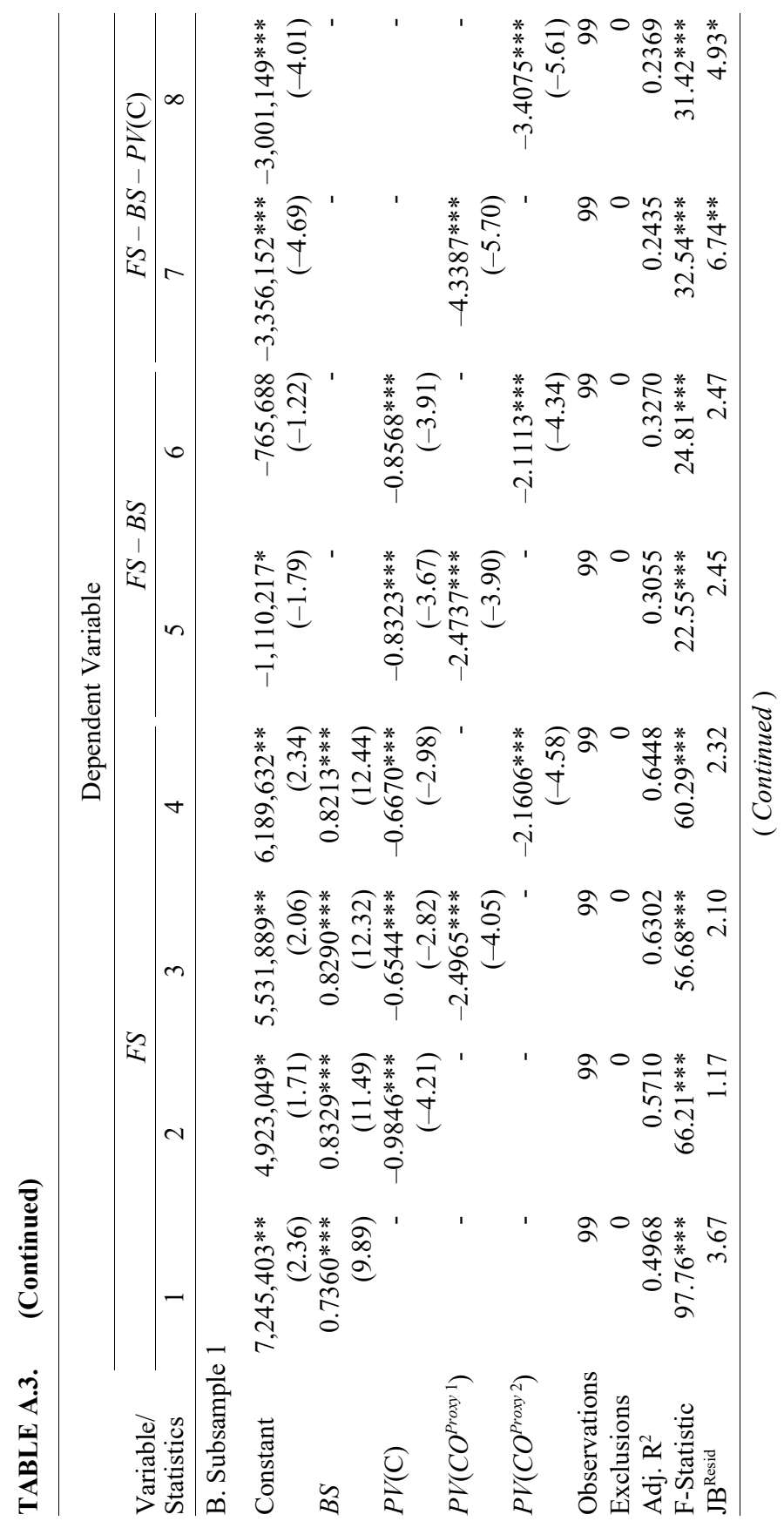




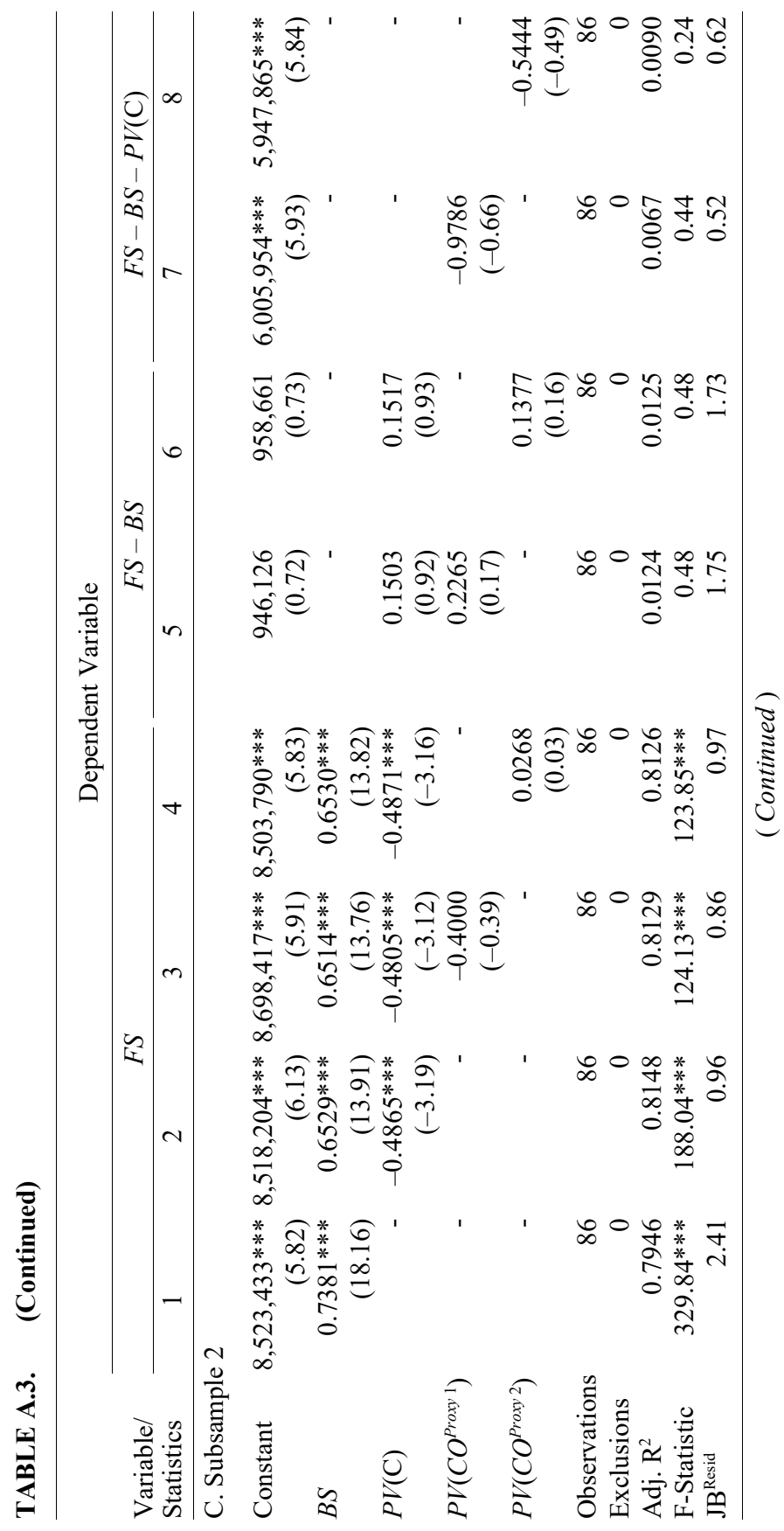




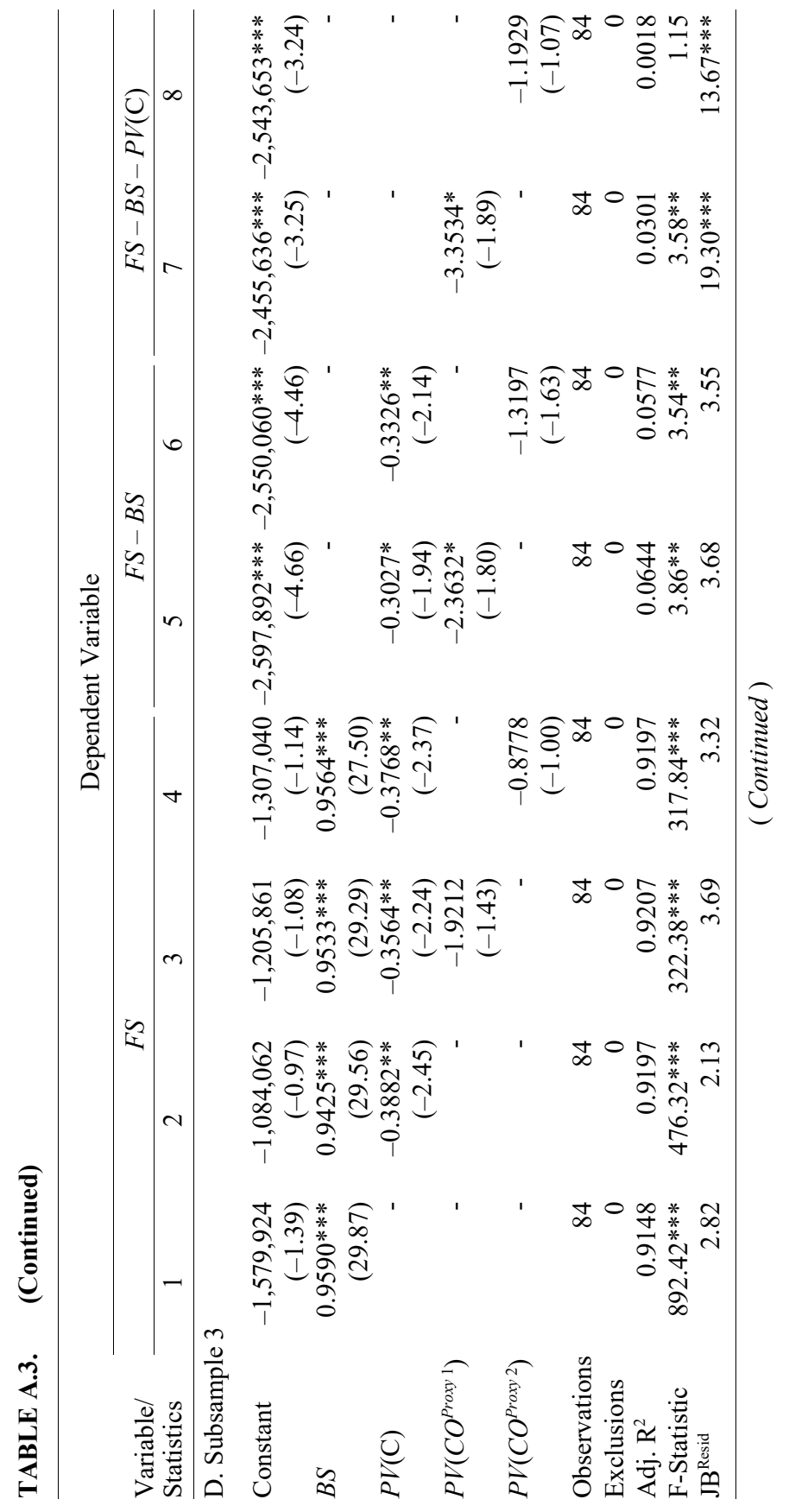




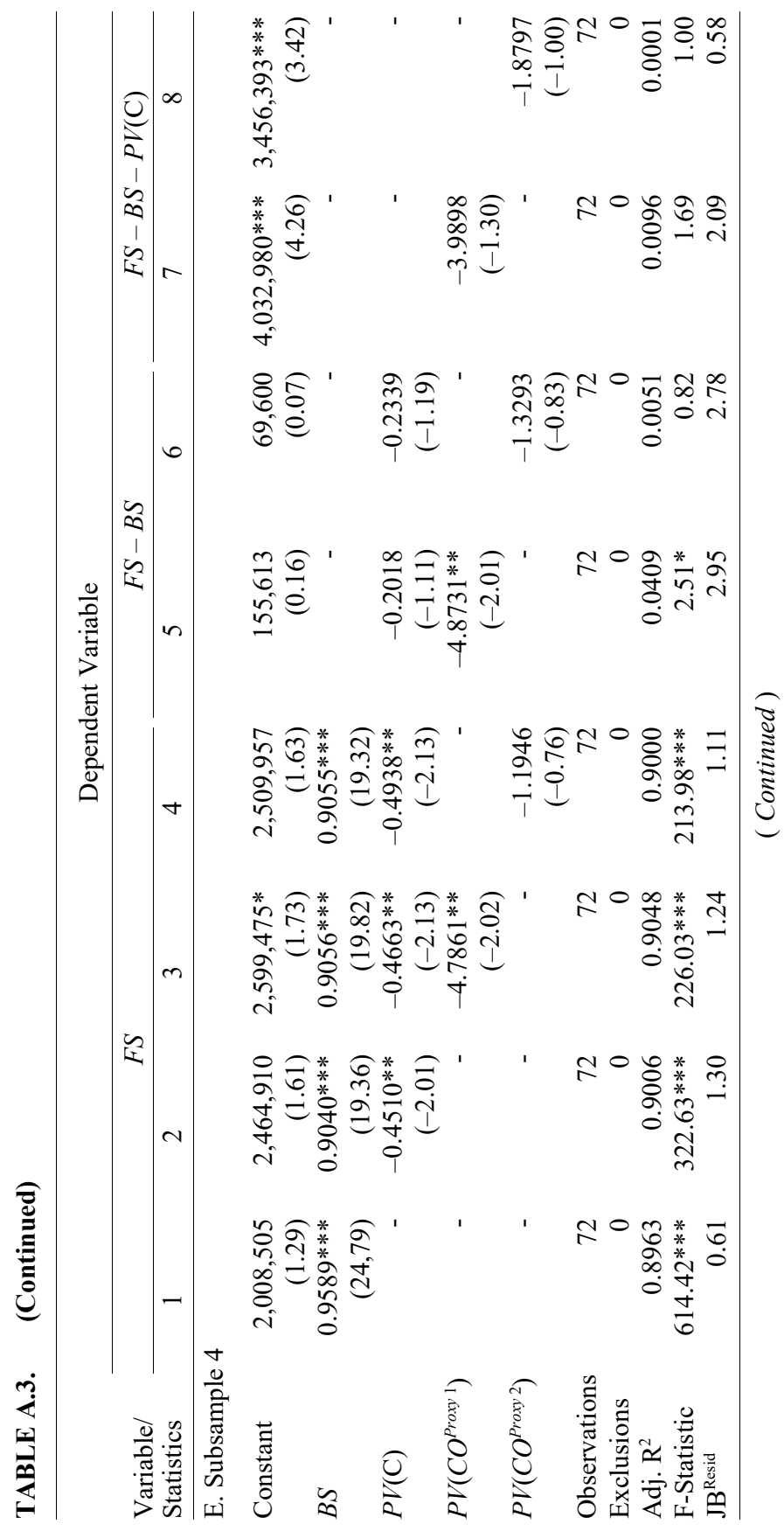




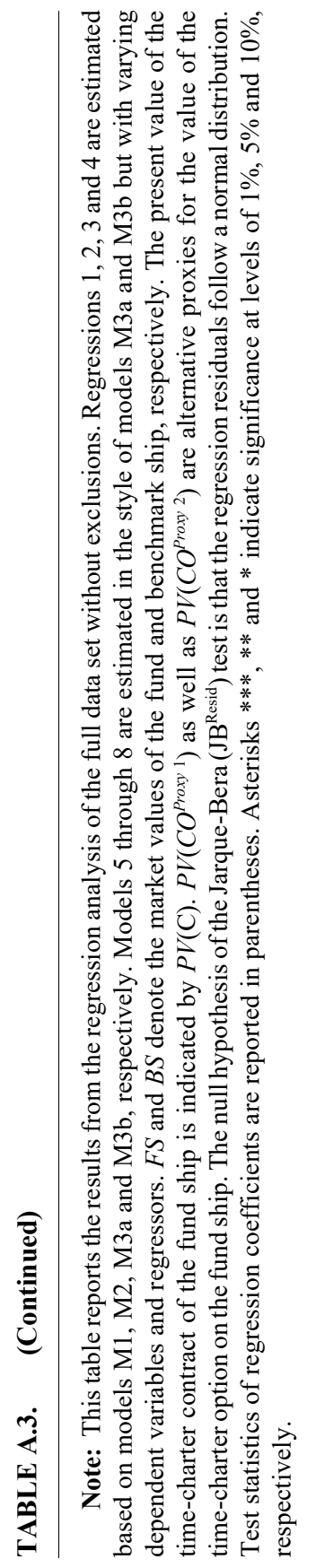




\section{References}

Ådland, R., and Cullinane, K. 2005. A time-varying risk premium in the term structure of bulk shipping freight rates. Journal of Transport Economics and Policy 39(2): 191-208.

Ådland, R., and Koekebakker, S. 2007. Ship valuation using cross-sectional sales data: A multivariate non-parametric approach. Maritime Economics \& Logistics 9(2): 105-118.

Albertijn, S.; Bessler, W.; and Drobetz, W. 2011. Financing shipping companies and shipping operations: A risk-management perspective. Journal of Applied Corporate Finance 23(4): 70-82.

Albertijn, S.; Drobetz, W.; and Johns, M. 2016. Maritime investment appraisal and budgeting. In M. G. Kavussanos and I. D. Visvikis (Eds.), The International Handbook of Shipping Finance. London: Palgrave Macmillan.

Alizadeh, A. H.; Ådland, R.; and Koekebakker, S. 2007. Predictive power and unbiasedness of implied forward charter rates. Journal of Forecasting 26(6): 385-403.

Alizadeh, A. H.; Kappou, K.; Tsouknidis, D.; and Visvikis, I. D. 2015. Liquidity effects and FFA returns in the international shipping derivatives market. Transportation Research Part E 76: 58-75.

Alizadeh, A. H., and Nomikos, N. K. 2009. Shipping Derivatives and Risk Management. Houndmills: Palgrave Macmillan.

Amihud, Y., and Mendelson, H. 1986. Asset pricing and the bid-ask spread. Journal of Financial Economics 17(2): 223-249.

Amihud, Y., and Mendelson, H. 2000. The liquidity route to a lower cost of capital. Journal of Applied Corporate Finance 12(4): 8-25.

Amihud, Y., and Mendelson, H. 2015. The pricing of illiquidity as a characteristic and as risk. Multinational Finance Journal 19(3): 149-168.

Baker, M., and Wurgler, J. 2007. Investor sentiment in the stock market. Journal of Economic Perspectives 21(2): 129-151.

Black, F. 1976. The pricing of commodity contracts. Journal of Financial Economics 3(4): 167-179.

Brown, S. J. 2011. The efficient markets hypothesis: The demise of the demon of chance? Accounting and Finance 51: 79-95.

Cherkes, M. 2012. Closed-end funds: A survey. Annual Review of Financial Economics 4(1): 431-445.

Chordia, T.; Roll, R.; and Subrahmanyam, A. 2008. Liquidity and market efficiency. Journal of Financial Economics 87(2): 249-268.

Cullinane, K., and Khanna, M. 2000. Economies of scale in large containerships: optimal size and geographical implication. Journal of Transport Economics and Policy 33(2): 185-208.

Cullinane, K., and Panayides, P. M. 2000. The use of capital budgeting techniques among UK-based ship operators. International Journal of Maritime Economics 2(4): 313-330. 
Datar, V. 2001. Impact of liquidity on premia/discounts in closed-end funds. Quarterly Review of Economics and Finance 41(1): 119-135.

Dimson, E.; Marsh, P.; and Staunton, M. 2011. Equity premiums around the world. In B. P. Hammond: M. L. Leibowitz: and L. B. Siegel (Eds.). Rethinking the Equity Risk Premium. Charlottesville: CFA Institute Research Foundation Publications.

Drobetz, W.; Gounopoulos, D.; Merikas, A. G.; and Schröder, H. 2013. Capital structure decisions of globally-listed shipping companies. Transportation Research Part E 52: 49-76.

Drobetz, W.; Schilling, D.; and Tegtmeier, L. 2010. Common risk factors in the returns of shipping stocks. Maritime Policy \& Management 37(2): 93-120.

Drobetz, W., and Tegtmeier, L. 2013. The development of a performance index for $\mathrm{KG}$ funds and a comparison with other shipping-related indices. Maritime Economics \& Logistics 15(1): 32-71.

Drobetz, W.; Tegtmeier, L.; and Topalov, M. 2008. Handelsplattformen für Schiffsbeteiligungen: Analyse und Vergleich von Zweitmärkten für Schiffsbeteiligungen unter Effizienzgesichtspunkten. Finanz Betrieb 10(1): 57-67.

Fama, E. F. 1970. Efficient capital markets: A review of theory and empirical work. Journal of Finance 25(2): 383-417.

Fama, E. F. 1991. Efficient capital markets: II. Journal of Finance 46(5): 1575-1617.

Feri Rating \& Research AG. (2010). Gesamtmarktstudie der Beteiligungsmodelle.

Fondsbörse Deutschland. 2015. Zahlen \& Fakten Juli 2015.

Glen, D. R., and Martin, B. T. 1998. Conditional modelling of tanker market risk using route specific freight rates. Maritime Policy \& Management 25(2): 117-128.

Grelck, M. B.; Prigge, S.; Tegtmeier, L.; and Topalov, M. 2014. Ein marktbasierter Index als Benchmark für Schiffsinvestitionen über Beteiligungstitel. Corporate Finance 5(7-8): 297-308.

Grelck, M. B.; Prigge, S.; Tegtmeier, L.; Topalov, M.; and Torpan, I. 2011. Investing in times of inflation fears: Diversification properties of investments in liquid real assets. Journal of Wealth Management 14(3): 44-57.

Grossman, S. J., and Stiglitz, J. E. 1980. On the impossibility of informationally efficient markets. American Economic Review 70(3): 393-408.

Harris, L. 1990. Liquidity, Trading Rules, and Electronic Trading Systems. New York: New York University.

Jiang, L., and Kryzanowski, L. 1997. Trading activity, quoted liquidity, and stock volatility. Multinational Finance Journal 1(3): 199-227.

Johns, M., and Sturm, C. 2015. The German KG System. In O. Schinas; M. Johns; and C. Grau (Eds.). HSBA Handbook on Ship Finance. Berlin: Springer. 
Johnson, T. C. 2008. Volume, liquidity, and liquidity risk. Journal of Financial Economics 87(2): 388-417.

Kavussanos, M. G. 1996. Comparisons of volatility in the dry-cargo ship sector: Spot versus time charters, and smaller versus larger vessels. Journal of Transport Economics and Policy 30(1): 67-82.

Kavussanos, M. G., and Alizadeh, A. H. 2002. The expectations hypothesis of the term structure and risk premiums in dry bulk shipping freight markets. Journal of Transport Economics and Policy 36(2): 267-304.

Kavussanos, M. G.; Juell-Skielse, A.; and Forrest, M. 2003. International comparison of market risks across shipping-related industries. Maritime Policy \& Management 30(2): 107-122.

Kavussanos, M. G., and Marcoulis, S. N. 2005. Cross-industry comparisons of the behaviour of stock returns in shipping, transportation and other industries. Research in Transportation Economics 12(4): 107-142.

Kavussanos, M. G., and Tsouknidis, D. 2014. The determinants of credit spreads changes in global shipping bonds. Transportation Research Part $E$ 70: 55-75.

Koekebakker, S., and Ådland, R. 2004. Modelling forward freight rate dynamics - empirical evidence from time charter rates. Maritime Policy \& Management 31(4): 319-335.

Küster Simic, A.; Prigge, S.; and Thönnessen, R. 2008. Informationseffizienz von Handelsplattformen für Schiffsfonds. In Hamburg Handelskammer (Ed.). Die Hamburger Börse 1558 - 2008: Trends im Börsenwesen. Hamburg: Murmann.

Küster Simic, A., and Thönnessen, R. 2008. Geschlossene Schifffonds Portfolio- und Marktrisiken: Eine empirische Untersuchung anhand von Zweitmarktkursdaten. Finanz Betrieb 10(7): 529-534.

Lee, C. M. C.; Shleifer, A.; and Thaler, R. H. 1991. Investor sentiment and the closed-end fund puzzle. Journal of Finance 46(1): 75-109.

Liu, W. 2006. A liquidity-augmented capital asset pricing model. Journal of Financial Economics 82(3): 631-671.

Madhavan, A. 2000. Market microstructure: A survey. Journal of Financial Markets 3(3): 205-258.

Markwardt, K., and Schröder, A. 2015. Equity capital market in shipping. In O. Schinas; M. Johns; and C. Grau (Eds.). HSBA Handbook on Ship Finance. Berlin: Springer.

Nomikos, N. K.; Kyriakou, I.; Papapostolou, N. C.; and Pouliasis, P. K. 2013. Freight options: Price modelling and empirical analysis. Transportation Research Part E 51: 82-94.

Ortiz-Molina, H., and Phillips, G. M. 2014. Real asset illiquidity and the cost of capital. Journal of Financial and Quantitative Analysis 49(1): 1-32.

Panayides, P. M.; Lambertides, N.; and Cullinane, K. 2013. Liquidity risk premium and asset pricing in US water transportation. Transportation Research Part E 52: 3-15. 
Pastor, L., and Stambaugh, R. F. 2003. Liquidity risk and expected stock returns. Journal of Political Economy 111(3): 642-685.

Pruyn, J. F. J.; van de Voorde, E.; and Meersman, H. 2011. Second hand vessel value estimation in maritime economics: A review of the past 20 years and the proposal of an elementary method. Maritime Economics \& Logistics 13(2): 213-236.

Pulvino, T. C. 1998. Do asset fire sales exist? An empirical investigation of commercial aircraft transactions. Journal of Finance 53(3): 939-978.

Roll, R.; Schwartz, E. S.; and Subrahmanyam, A. 2007. Liquidity and the law of one price: The case of the futures/cash basis. Journal of Finance 62(5): 2201-2234.

Rygaard, J. M. 2009. Valuation of time charter contracts for ships. Maritime Policy \& Management 36(6): 525-544.

Schindler, F. 2013. Predictability and persistence of the price movements of the $\mathrm{S} \& \mathrm{P} /$ Case-Shiller house price indices. Journal of Real Estate Finance and Economics 46(1): 44-90.

Schmidt, H. 1977. Vorteile und Nachteile eines integrierten Zirkulationsmarktes für Wertpapiere gegenüber einem gespaltenen Effektenmarkt. Luxembourg: Commission of the European Communities.

Scope Analysis GmbH. 2013. Emissionsführer Geschlossene Fonds.

Stoll, H. R. 1992. Principles of trading market structure. Journal of Financial Services Research 6(1): 75-106.

Stopford, M. 2009. Maritime Economics. New York: Routledge.

Syriopoulos, T. C., and Roumpis, E. 2009. Asset allocation and value at risk in shipping equity portfolios. Maritime Policy \& Management 36(1): 57-78.

Tegtmeier, L., and Topalov, M. 2007. Kapitalstruktur und Tilgungsverhalten von geschlossenen Schiffsfonds. Finanz Betrieb 9(4): 247-254.

Tobin, J. (1984). On the efficiency of the financial-system. Lloyds Bank Annual Review 153: 1-15.

Veenstra, A. W., and van Dalen, J. 2011. Speed and fuel consumption quotation in ocean shipping time charter contracts. Journal of Transport Economics and Policy 45(1): 41-61.

Wright, G. 2007. Term risk premia in shipping markets: Reconciling the evidence. Journal of Transport Economics and Policy 41(2): 247-256. 